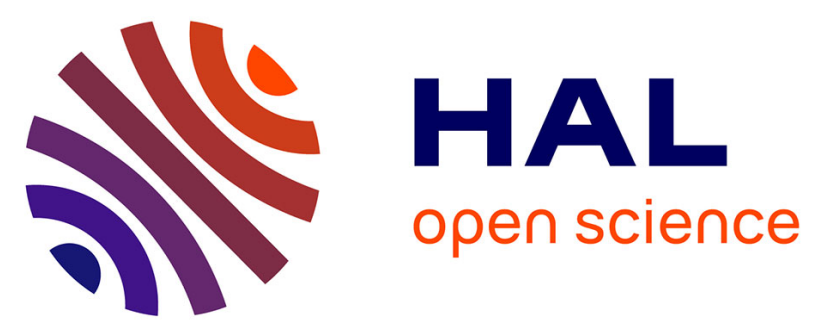

\title{
Repeated exposure of Caco-2 versus Caco-2/HT29-MTX intestinal cell models to (nano)silver in vitro: Comparison of two commercially available colloidal silver products
}

Kevin Gillois, Charlotte Stoffels, Mathilde Lévêque, Isabelle Fourquaux, Justine Blesson, Valérie Mils, Sébastien Cambier, Julien Vignard, Hélène Terrisse, Gladys Mirey, et al.

\section{- To cite this version:}

Kevin Gillois, Charlotte Stoffels, Mathilde Lévêque, Isabelle Fourquaux, Justine Blesson, et al.. Repeated exposure of Caco-2 versus Caco-2/HT29-MTX intestinal cell models to (nano)silver in vitro: Comparison of two commercially available colloidal silver products. Science of the Total Environment, 2021, 754, 10.1016/j.scitotenv.2020.142324 . hal-02945727

\section{HAL Id: hal-02945727 \\ https://hal.inrae.fr/hal-02945727}

Submitted on 23 Mar 2021

HAL is a multi-disciplinary open access archive for the deposit and dissemination of scientific research documents, whether they are published or not. The documents may come from teaching and research institutions in France or abroad, or from public or private research centers.
L'archive ouverte pluridisciplinaire HAL, est destinée au dépôt et à la diffusion de documents scientifiques de niveau recherche, publiés ou non, émanant des établissements d'enseignement et de recherche français ou étrangers, des laboratoires publics ou privés.

\section{(이) $\$$}

Distributed under a Creative Commons Attribution - NonCommercial - NoDerivatives 44.0 


\section{Repeated exposure of Caco-2 versus Caco-2/HT29-MTX intestinal cell models to (nano)silver in vitro: comparison of two commercially available colloidal silver products}

Kévin GILLOIS ${ }^{1}$, Charlotte STOFFELS², Mathilde LEVEQUE ${ }^{1}$, Isabelle FOURQUAUX ${ }^{3}$, Justine BLESSON ${ }^{1}$, Valérie MILS ${ }^{1}$, Sébastien CAMBIER $^{2}$, Julien VIGNARD ${ }^{1}$, Hélène TERRISSE ${ }^{4}$, Gladys MIREY ${ }^{1}$, Jean-Nicolas AUDINOT², Vassilia THEODOROU ${ }^{1}$, MarieHélène ROPERS ${ }^{5}$, Hervé ROBERT ${ }^{1}$, and Muriel MERCIER-BONIN ${ }^{1, *}$

1 - Toxalim, Université de Toulouse, INRAE, INP-ENVT, INP-EI-Purpan, Université de Toulouse 3 Paul Sabatier, Toulouse, France.

2 - Luxembourg Institute of Science and Technology (LIST), 41, rue de Brill, Belvaux, L-4422, Luxembourg.

3 - Centre de Microscopie Électronique Appliquée à la Biologie, CMEAB, 133 route de Narbonne, 31062 Toulouse, France.

4 - Université de Nantes, CNRS, Institut des Matériaux Jean Rouxel, IMN, F-44000 Nantes, France

5 - INRAE, UR BIA, F-44316, Nantes, France.

${ }^{*}$ Corresponding author: Muriel Mercier-Bonin, PhD, Toxalim, UMR INRAE 1331, 180 chemin de Tournefeuille, BP 93173, 31027 TOULOUSE cedex 3, France; Tel: +33 (0)5 820664 58; E-mail: muriel.mercier-bonin@inrae.fr 


\begin{abstract}
Colloidal silver products are sold for a wide range of disinfectant and health applications. This has increased the potential for human exposure to silver nanoparticles (AgNPs) and ions ( $\mathrm{Ag}^{+}$), for which oral ingestion is considered to be a major route of exposure. Our objective was to evaluate and compare the toxicity of two commercially available colloidal silver products on two human intestinal epithelial models under realistic exposure conditions.
\end{abstract}

Mesosilver ${ }^{\mathrm{TM}}$ and AgC were characterized and a concentration range between 0.1 and $12 \mu \mathrm{g} / \mathrm{mL}$ chosen. Caco-2 cells vs co-culture of Caco-2 and mucus-secreting HT29-MTX cells (90/10) were used. Repeated exposure was carried out to determine cell viability over 18 days of cell differentiation in 24-well plates. Selected concentrations $(0.1,1$, and $3 \mu \mathrm{g} / \mathrm{mL})$ were tested on cells cultured in E-plates and Transwells with the same repeated exposure regimen, to determine cell impedance, and cell viability and trans-epithelial electrical resistance (TEER), respectively. Silver uptake, intracellular localisation, and translocation were determined by CytoViva ${ }^{\mathrm{TM}}$, HIM-SIMS, and ICP-MS. Genotoxicity was determined on acutely-exposed proliferating Caco2 cells by $\gamma \mathrm{H} 2 \mathrm{AX}$ immunofluorescence staining.

Repeated exposure of a given concentration of AgC, which is composed solely of ionic silver, generally exerted more toxic effects on Caco-2 cells than Mesosilver ${ }^{\mathrm{TM}}$, which contains a mix of AgNPs and ionic silver. Due to its patchy structure, the presence of mucus in the Caco2/HT29-MTX co-culture only slightly mitigated the deleterious effects on cell viability. Increased genotoxicity was observed for AgC on proliferating Caco-2 cells. Silver uptake, intracellular localisation, and translocation were similar.

In conclusion, Mesosilver ${ }^{\mathrm{TM}}$ and AgC colloidal silver products show different levels of gut toxicity due to the forms of distinct silver (AgNPs and/or $\mathrm{Ag}^{+}$) contained within. This study 
highlights the applicability of high-resolution (chemical) imaging to detect and localize silver and provides insights into its uptake mechanisms, intracellular fate and cellular effects.

\section{Keywords}

colloidal silver; silver nanoparticles; repeated exposure in vitro; gut toxicity; genotoxicity; high-resolution chemical imaging 


\section{Introduction}

Silver nanoparticles (AgNPs) are increasingly used in a wide range of consumer products, such as cleaning products, food storage containers, personal care products, and dietary supplements (Tulve et al., 2015), as inventoried by the project on Emerging Nanotechnologies (The Woodrow Wilson International Center for Scholars 2019). The high surface area of AgNPs allows for redox-driven dissolution and the release of ionic silver $\left(\mathrm{Ag}^{+}\right)$, which provides broadspectrum antimicrobial properties to products (Wijnhoven et al., 2009). Amongst the forms consumed by humans, AgNPs may be present in colloidal silver (defined as a suspension of silver-containing particles between 1 and $1000 \mathrm{~nm}$ in size), commercially available as over-thecounter (OTC) drug products and proposed in the US and Europe as a dietary supplement (Reed et al., 2014; Rong et al., 2018) for the claimed benefits of supporting a healthy human immune system. Although the Food and Drug Administration (FDA) did not recognize OTC colloidal silver products as safe and effective in 1999 (FR Doc. 99-21253), the sale of colloidal silver as a dietary supplement is not prohibited, as Federal law does not require it to be proven safe or to have health benefits. In Europe, silver no longer appears on the list of vitamins and minerals authorized in food supplements (directive 2002/46/EC of the European Parliament and of the Council in June 2002).

The intentional oral uptake of colloidal silver dietary supplements represents the most direct exposure route of silver for humans, which can result in exposure of up to $0.02 \mathrm{mg} / \mathrm{kg}$ body weight/day (Larsen et al., 2015). From a risk assessment perspective, understanding their fate, cellular uptake, and bioavailability upon ingestion is of paramount importance to assess their impact on human health. As the first line of defence, as well as the portal of entry and target for AgNPs, the gut has been extensively studied in terms of toxicological endpoints, mainly in vitro 
and under high-concentration and acute-exposure conditions. Cellular uptake, oxidative stress, cytotoxic, genotoxic, and/or inflammatory effects have been reported, despite conflicting findings, explained by different concentration ranges, in vitro cellular models, methods of detection, and physico-chemical characteristics of the AgNPs under study (Pietroiusti et al., 2017). However, these in vitro studies were mainly focused on commercially available or laboratory-synthesized nanoparticles, which are not fully representative of the ingested forms present in colloidal silver dietary supplements. Thus, it is critical to evaluate the effects of "real" ingested AgNPs, which exhibit specific physico-chemistry, behaviour, and gut toxicity, under realistic conditions that mimic human exposure (i.e. low dose, repeated exposure). Rogers et al. (2018) and later De Leersnyder et al. (2020) characterized large panels of commercially available silver-containing products and reported high variability in the $\mathrm{AgNP} / \mathrm{Ag}^{+}$ concentration, AgNP size/shape, and AgNP/Ag ${ }^{+}$ratio (De Leersnyder et al., 2020; Rogers et al., 2018), confirming previous results obtained on drinkable colloidal silver-containing products (Cascio et al., 2015). Recent studies have explored the fate of commercial colloidal silver supplements in simulated human digestive environments (Rogers et al., 2020; Rong et al., 2018; Wu et al., 2018). In particular, Mesosilver ${ }^{\mathrm{TM}}$, composed of monodisperse spherical AgNPs (mean diameter of $9.5 \pm 5.0 \mathrm{~nm}$ ), with a $90 \% \mathrm{AgNPs} / 10 \% \mathrm{Ag}^{+}$ratio, has been shown to be much more reactive than both laboratory synthesized and commercially available AgNPs, possibly due to differences in their intrinsic physico-chemical properties (such as size and surface charge) (Rong et al., 2018). Little is known about the toxic effects of these commercially available products in vitro. Rogers et al. (2020) reported cytotoxicity of five commercial colloidal silver spray products, which was attributed to the particulate silver, soluble silver, and/or non-silver matrix constituents, using a rat intestinal epithelial cell (IEC-6) model. In addition, Reed et al. (2014) observed a decrease in the number of microvilli in human intestinal 
Caco-2 cells treated with liquid AgNP-containing dietary supplements relative to untreated cells.

Based on these data, the gut toxicity of two commercially available colloidal silver products, Mesosilver ${ }^{\mathrm{TM}}$ and AgC, was evaluated in vitro under realistic conditions (i.e. low dose and repeated exposure) to mimic human chronic exposure (Chen et al., 2016; Vila et al., 2017). Two intestinal epithelial cell models were considered and compared: (i) a Caco-2 monoculture which is a widely used model of intestinal barrier function for toxicological studies (Böhmert et al., 2015; Imai et al., 2017; Juling et al., 2017; Lichtenstein et al., 2015; Vila et al., 2018) and (ii) a Caco-2/HT29-MTX co-culture as a more physiologically relevant intestinal model to mimic a mucus-producing epithelium (Béduneau et al., 2014; Hilgendorf et al., 2000; Lozoya-Agullo et al., 2017). Mucus is indeed the first physical and chemical barrier against toxicants (Gillois et al., 2018), particularly AgNPs (Bi et al., 2020), as illustrated in a Caco-2/HT29-MTX co-culture following $24 \mathrm{~h}$ of acute exposure (Abdelkhaliq et al., 2020; Georgantzopoulou et al., 2016). In the present study, the following toxicological endpoints, typically used for AgNPs (Böhmert et al., 2014; Saez-Tenorio et al., 2019; Vila et al., 2018) were prioritised for the assessment of colloidal silver toxicity to Caco-2 and Caco-2/HT29-MTX cells: cytotoxicity, genotoxicity, real-time monitoring of cell impedance, and trans-epithelial electrical resistance, as well as silver uptake, intracellular localisation, and translocation. High-resolution chemical imaging (Helium Ion Microscope coupled to a Secondary Ion Mass Spectrometer (HIM-SIMS)) was used, for the first time, in combination with CytoViva ${ }^{\mathrm{TM}}$ hyperspectral imaging, as developed to study AgNPs by Fizeşan et al. (2019).

\section{Materials and Methods}




\subsection{Colloidal silver products and chemicals}

A suspension of Mesosilver ${ }^{\mathrm{TM}}(20 \mu \mathrm{g} / \mathrm{mL})$, sold as a dietary supplement, was purchased in 2018 from Purest Colloids, Inc (Westampton, NJ, USA). A Colloidal Silver product (15 $\mu \mathrm{g} / \mathrm{mL})$, sold for external use in health and disinfectant applications (hereafter referred to as AgC), was also purchased in 2018 from the Laboratoire Bio Colloidal (Saint-Fort, France). Both colloidal silver products were stored at room temperature in the dark. Phosphate buffered saline (PBS), bovine serum albumin (BSA, CAS N9048-46-8, $\geq 98 \%$ ), and Triton X-100 (CAS N9002-93-1, $\geq$ 97\%) were obtained from Euromedex (Souffelweyersheim, France). Dulbecco's Modified Eagle’s Medium with phenol red (DMEM) 10X (CAT\#D2429) and 1X (CAT\#5546), fetal bovine serum (FBS), penicillin/streptomycin, D-(+)-glucose (CAS N50-99-7), sodium bicarbonate (CAS $N^{\circ} 144-55-8, \geq 99.7 \%$ ), and folic acid (CAS $N^{\circ 59-30-3, ~ \geq ~ 97 \%) ~ w e r e ~}$ obtained from Sigma (Saint-Quentin Fallavier, France). Non-essential amino acids (NEAA), Glutamax and Tryple Express were obtained from Gibco (Illkirch, France). AlamarBlue ${ }^{\circledR}$ reagent, Alexa Fluor 488 goat anti-mouse IgG antibody, and ProLong Gold antifade reagent with DAPI (4',6-diamidino-2-phenylindole) were obtained from Invitrogen (Eugene, OR, USA). Mouse anti-phospho-Histone2AX (Ser139) antibody clone JBW301 was obtained from Merck Millipore (Molsheim, France). Calicheamicin-ү1 (CAS N¹08212-75-5, 98.44\%) was obtained from Pfizer (Paris, France). Epon resin (Embed 812), formaldehyde solution (CAS N50-00-0, 16\%), glutaraldehyde (CAS N¹11-30-8, 25\%), osmium tetroxide (CAS N²081612-0, 4\%), and Sorensen phosphate buffer were obtained from Electron Microscopy Sciences (Hatfield, PA, USA). $\mathrm{HNO}_{3}$ (CAS N7697-37-2) was obtained from ChemLab (Zedelgem, Belgique).

\subsection{Physico-chemical characterization of Mesosilver ${ }^{\mathrm{TM}}$ and AgC}




\subsubsection{Transmission electron microscopy (TEM)}

TEM was used to determine the size and shape of the AgNPs in the colloidal silver suspensions. Samples were prepared by depositing a drop of the colloidal suspension onto a carbon-coated copper grid and allowing it to air-dry at room temperature. TEM images were obtained using a Hitachi H-9000 NAR (300 kV, Scherzer resolution $0.18 \mathrm{~nm}$; Tokyo, Japan) coupled to an energy dispersive X-ray spectrometer (EDX, Kevex; Valencia, CA, USA) to confirm the presence of silver. Images representative of 10 different locations and 580 particles on the grid were processed using the program Image $\mathrm{J}$ (National Institutes of Health) to determine the shape and size distribution of the nanoparticles.

\subsubsection{Dynamic and electrophoretic light scattering}

The hydrodynamic diameter and zeta potential of AgNPs in the colloidal silver products or suspended at $3 \mu \mathrm{g} / \mathrm{mL}$ in DMEM culture medium (with or without $2 \%$ (v/v) FBS) were determined by dynamic light scattering (DLS) and electrophoretic light scattering (ELS), respectively, using a Zetasizer Nano ZS (Malvern, Orsay, France). AgNP suspensions were kept in an incubator $\left(37^{\circ} \mathrm{C}, 5 \% \mathrm{CO}_{2} / 95 \%\right.$ air) for 0 to $48 \mathrm{~h}$ and analysed at various timepoints. Measurements were performed in triplicate at a controlled temperature of $25^{\circ} \mathrm{C}$ in a folded capillary zeta cell (Malvern) with a 633-nm laser source and a scattering angle of $173^{\circ}$. The intensity size distribution, diameter at the maximum peak, and polydispersity index (PDI) were determined.

\subsubsection{UV-Vis spectroscopy}

Modifications of the AgNP suspension (3 $\mu \mathrm{g} / \mathrm{mL}$ ) in DMEM culture medium (with or without 2\% (v/v) FBS) over time were measured by UV-vis spectroscopy. The absorbance spectrum of AgNP samples from 300 to $500 \mathrm{~nm}$ was recorded at room temperature in UV microplates 
(Greiner Bio-One, Frickenhausen, Germany) using a SPARK spectrophotometer (TECAN, Männedorf, Switzerland). Culture medium, with or without FBS, was used as a blank, depending on the condition to be tested. Three independent experiments were performed.

\subsection{Cell lines and cell culture}

The human colon adenocarcinoma Caco-2 cell line was obtained from the European Collection of Cell Cultures (ECACC, Salisbury, UK). The mucus-secreting colon adenocarcinoma HT29MTX cell line was kindly provided by Dr. Thécla Lesuffleur (INSERM Lille). Cells were used at passage 49-55 and 9-15 for Caco-2 and HT29-MTX, respectively. Both cell lines were maintained in DMEM with phenol red and 4.5g/L D-(+)-glucose, supplemented with 1\% (v/v) penicillin/streptomycin, 1\% (v/v) NEAA, 1\% (v/v) Glutamax, and 10\% (v/v) heat-inactivated FBS at $37^{\circ} \mathrm{C}$ in a humidified atmosphere of $5 \% \mathrm{CO}_{2} / 95 \%$ air. The culture medium was changed every 2 to 3 days and the cells were split upon confluency using Tryple Express.

\subsection{Repeated cell exposure to Mesosilver ${ }^{\mathrm{TM}}$ and AgC suspensions}

A schematic representation of the experimental design is presented in Figure S1. For all experiments with Caco-2 and Caco-2/HT29-MTX cultures to be performed in 24-well plates (Corning Costar, Kaiserslautern, Germany), E-plates (Ozyme, Saint-Cyr-l'École, France), and $6.5 \mathrm{~mm}$ polycarbonate membrane Transwell systems with a $0.4-\mu \mathrm{m}$ pore size (Corning Costar), cells were seeded at 150,000 cells per $\mathrm{cm}^{2}$, at a 90/10 ratio for the co-culture, and grown at $37^{\circ} \mathrm{C}$ until day 10 under the culture conditions described above. At day 10, the medium was discarded and the cells washed with PBS. Then, a new culture medium was used for treatment, based on 10X DMEM and diluted to $1 \mathrm{X}$ with a final concentration of $4.5 \mathrm{~g} / \mathrm{L} \mathrm{D-(+)-glucose,}$ 3.7 $\mathrm{g} / \mathrm{L}$ sodium bicarbonate, $0.004 \mathrm{~g} / \mathrm{L}$ folic acid, $1 \%$ (v/v) penicillin/streptomycin, 1\% (v/v) NEAA, 1\% (v/v) Glutamax, 2\% (v/v) FBS, and various concentrations of Mesosilver ${ }^{\mathrm{TM}}$ or AgC 
suspension (concentration range between 0.1 and $12 \mu \mathrm{g} / \mathrm{mL}$; diluted with sterilized milliQ grade water). This medium was added every 2 days from day 10 for 18 days of cell differentiation. The control condition corresponded to the same treatment medium with sterilized milliQ grade water replacing the silver-containing product. At the end of the exposure period, samples were collected for further analysis.

\subsubsection{Cellular viability}

The AlamarBlue ${ }^{\circledR}$ assay was used to evaluate the viability of cells grown on 24-well plates or Transwells and treated with Mesosilver ${ }^{\mathrm{TM}}$ - or AgC (concentrations of 0.1-12 $\mu \mathrm{g} / \mathrm{mL}$ and 0.1, 1, and $3 \mu \mathrm{g} / \mathrm{mL}$, respectively). At the end of treatment as described above, the cell culture medium was removed and the cells washed with PBS at $37^{\circ} \mathrm{C}$ before adding diluted AlamarBlue ${ }^{\circledR}(1: 10$ dilution) in minimal medium (DMEM without FBS) and incubation for $3 \mathrm{~h}$ at $37^{\circ} \mathrm{C}$. The medium was then transferred to a microplate reader and the fluorescence immediately measured at $570 \mathrm{~nm}$ excitation and $610 \mathrm{~nm}$ emission using a SPARK spectrophotometer. Three independent experiments were performed, at least in triplicate.

\subsubsection{Cell impedance}

Cell impedance was monitored in situ and in real-time using an xCELLigence system (ACEA Biosciences, San Diego, USA). The impedance measurement is based on the effect of the cells, attached to the xCELLigence electrodes, on the local ionic environment at the electrodesolution interface. Impedance depends on the number of attached cells and their interaction with the electrodes. An increase in cell number, cell adhesion, and/or spreading results in a change in electrode impedance, which is displayed as a cell index (CI) value. Caco-2 or Caco-2/HT29MTX cells, grown on E-plates, were repeatedly treated with the Mesosilver ${ }^{\mathrm{TM}}$ or AgC suspension (concentration of $0.1,1$, and $3 \mu \mathrm{g} / \mathrm{mL}$ ) vs. control, as already described. Cell 
impedance was measured every day during the 18-day exposure period. Three independent experiments were performed in triplicate.

\subsubsection{Trans-epithelial electrical resistance}

The trans-epithelial electrical resistance (TEER) of Caco-2 monocultures and Caco-2/HT29MTX co-cultures was continuously monitored using a cellZScope version 2 (nanoAnalytics, Münster, Germany). Cells were grown on Transwells in 10\% (v/v) FBS medium until day 9 and transferred to the cellZScope device for a 24-h stabilization in the same medium. At day 10, basal TEER values were measured. Then, the medium was removed and cells repeatedly exposed at the apical side to the Mesosilver ${ }^{\mathrm{TM}}$ or AgC suspension (concentrations of 1 and 3 $\mu \mathrm{g} / \mathrm{mL}$ ) vs. control for 18 days, as already described. The medium from the basolateral side was replaced every 2 to 3 days with DMEM 2\% (v/v) FBS at the same time as the treatment medium was refreshed on the apical side. TEER was monitored daily during the 18-day exposure period. Three independent experiments were performed in triplicate.

2.4.4 Silver uptake, intracellular fate and translocation from apical to basolateral compartments

\subsubsection{Sample preparation}

At the end of the exposure period (day 28) to Mesosilver ${ }^{\mathrm{TM}}$ or AgC suspension (concentration of $3 \mu \mathrm{g} / \mathrm{mL}$ ), Transwells were fixed in $2 \%$ glutaraldehyde in $0.1 \mathrm{M}$ Sorensen phosphate buffer (pH 7.4) overnight at $4^{\circ} \mathrm{C}$, washed overnight in $0.2 \mathrm{M}$ phosphate buffer and then post-fixed for $1 \mathrm{~h}$ at room temperature with $1 \%$ osmium tetroxide in $250 \mathrm{mM}$ glucose and $0.05 \mathrm{M}$ phosphate buffer. The samples were then dehydrated in a series of graded ethanol solutions; membranes were cut out from the wells and embedded in an Epon resin. Finally, samples were sliced into 300-nm semi-thin sections and mounted on microscope glass slides for high-resolution dark- 
field hyperspectral imaging (CytoViva ${ }^{\mathrm{TM}}$ ) and silicon wafers for high-resolution chemical imaging (Helium Ion Microscope coupled with a Secondary Ion Mass Spectrometer, HIMSIMS).

\subsubsection{CytoViva ${ }^{\mathrm{TM}}$}

CytoViva $^{\mathrm{TM}}$ analyses were carried out as previously described by Mehennaoui et al. (2018). The semi-thin layers were covered with a drop of mineral oil without the need of a cover slide, as the samples were embedded in Epon-resin, making them inert to mineral oil. The samples were visualized using a CytoViva ${ }^{\mathrm{TM}}$ dark-field hyperspectral imaging system (CytoViva Inc., Auburn, Alabama, USA) mounted on Olympus BX-43 optical microscope. Images of the samples were captured at 60-fold magnification with oil immersion using a hyperspectral camera controlled by environment for visualization ENVI software (version 4.8 from Harris Corporation, Melbourne, FL, USA and modified by CytoViva ${ }^{\mathrm{TM}}$, Inc.). Spectral libraries of exposed cells were manually generated, with approximately 200 spectra acquired per sample. Acquired libraries were filtered against non-exposed samples to filter out all spectra non-related to AgNPs or Ag colloids using a spectral angle mapper (SAM) algorithm with a 0.05-radian tolerance. Filtered libraries were mapped onto images of exposed samples using SAM with a 0.05-radian tolerance, which allows highlighting similarities between the spectra in the image and spectral library. The signature of AgNPs and/or Ag colloids was artificially red-tagged using ImageJ software (National Institutes of Health, Bethesda, MD). One sample for each condition was used for image analysis.

2.4.4.3 Helium Ion Microscope coupled with a Secondary Ion Mass Spectrometer (HIMSIMS) 
Secondary Ion Mass spectrometry (SIMS) images were acquired with a HIM-SIMS (Zeiss, Peabody, US) using $\mathrm{Ne}^{+}$primary bombardment accelerated at $20 \mathrm{keV}$. The lateral resolution was in the range 20 to $30 \mathrm{~nm}$, with an intensity of $1.5 \mathrm{pA}$. Both polarities, positive and negative, were used for the respective detection of ion silver $\left({ }^{107} \mathrm{Ag}^{+}\right)$and the ion cluster ${ }^{12} \mathrm{C}^{14} \mathrm{~N}^{-}$. Images were recorded as a matrix of 512 x 512 image points with a counting time of $5 \mathrm{~ms} /$ pixel. One sample for each condition was used for image analysis.

\subsubsection{Inductively Coupled Plasma - Mass Spectrometry (ICP-MS)}

Silver (AgNPs and/or ionic silver) translocation from the apical to basolateral compartments was determined by measuring the silver concentration in both compartments by Inductively Coupled Plasma - Mass Spectrometry (ICP-MS). At the end of the exposure period (day 28) to Mesosilver $^{\mathrm{TM}}$ or AgC suspension $(3 \mu \mathrm{g} / \mathrm{mL})$, all the medium from the apical (300 $\left.\mu \mathrm{L}\right)$ and basolateral $(800 \mu \mathrm{L})$ compartments of each Transwell was collected into $1.5 \mathrm{~mL}$ microtubes. Samples were concentrated by evaporation with a SpeedVac concentrator (Thermo Fisher Scientific, Illkirch, France) at $35^{\circ} \mathrm{C}$ for $2 \mathrm{~h}$ and stored one week at $-80^{\circ} \mathrm{C}$ before use. Samples were then digested in $65 \% \mathrm{HNO}_{3}$ for 30 min to obtain a perfectly clear solution and then water was added to obtain a $2 \% \mathrm{HNO}_{3}$ solution for ICP-MS-Q analysis (Varian 820-MS quadrupole inductively-coupled plasma spectrometer; Melbourne, Australia). Measurements on two samples for each condition were performed in the Laboratoire de Planétologie et Géodynamique (LPG Nantes laboratory, UMR 6112, France). The total silver concentration was determined by external calibration using certified single-element reference standard solutions (IONEX reference standard from ChemLab, Zedelgem, Belgium at $1000 \mu \mathrm{g} / \mathrm{mL}$ ). Each standard was prepared to obtain a $2 \% \mathrm{HNO}_{3}$ solution, as for the samples. Two isotopes of silver were analysed $\left({ }^{107} \mathrm{Ag}\right.$ and $\left.{ }^{109} \mathrm{Ag}\right)$ and gave consistent results. ${ }^{115} \mathrm{In}$ was used as an internal standard. 


\subsection{DNA damage analysis}

DNA damage in proliferating Caco-2 cells was detected using antibodies against phosphorylated histone $\mathrm{H} 2 \mathrm{AX}(\gamma \mathrm{H} 2 \mathrm{AX})$, a marker of DNA double-strand breaks (DSBs) (Bonner et al., 2008; Rogakou et al., 2000). First, 150,000 Caco-2 cells/cm² were seeded on coverslips. After $24 \mathrm{~h}$ to allow attachment, the cells were exposed for 1, 6, or $24 \mathrm{~h}$ to 0.1 , 1, or $3 \mu \mathrm{g} / \mathrm{mL}$ Mesosilver ${ }^{\mathrm{TM}}$ or AgC suspension. Exposure to $500 \mathrm{fM}$ calicheamicin was used as a positive control for inducing genotoxicity. At the end of treatment, cells were immediately fixed with 4\% paraformaldehyde in PBS. After PBS washing, cells were permeabilized with $0.1 \%$ Triton X-100, washed in PBS, and blocked in PBS with 1\% BSA overnight. After blocking, cells were incubated with mouse anti-phospho-Histone2AX (Ser139) antibody clone JBW301 at a 1:1,000 dilution, followed by incubation with Alexa Fluor 488 goat anti-mouse IgG antibody at a 1:100 dilution. Coverslips were mounted using ProLong Gold antifade reagent with DAPI to counterstain the nuclei. Slides were visualized under a $40 \times$ objective on a Leica TCS SP8 AOBS inverted confocal microscope (Leica Microsystems, Mannheim, Germany). The number of $\gamma \mathrm{H} 2 \mathrm{AX}$ positive cells, expressed as the percentage of the total cell number, was calculated, based on the determination of a threshold of $\gamma \mathrm{H} 2 \mathrm{AX}$ intensity for untreated cells. The intensity of $\gamma \mathrm{H} 2 \mathrm{AX}$ was compared to this threshold for each treated cell, visualized with DAPI staining. A minimum of 50 cells per image and eight images for each condition were analysed in a blinded fashion.

\subsection{Statistical analysis}

Data are expressed as the mean \pm standard error (SD). Statistical significance was calculated using one-way or two-way ANOVA with Dunnett's multiple comparison test using GraphPad Prism software version 8.3 for Windows (GraphPad Software, San Diego, CA). Differences were considered statistically significant for a p-value $<0.05$. 


\section{Results}

\subsection{Characterisation of Mesosilver ${ }^{\mathrm{TM}}$ and $\mathrm{AgC}$ suspensions in pure form and diluted in cell-culture medium}

The physico-chemical properties of Mesosilver ${ }^{\mathrm{TM}}(20 \mu \mathrm{g} / \mathrm{mL})$ and AgC $(15 \mu \mathrm{g} / \mathrm{mL})$ suspensions, in their pure form or diluted in culture medium (containing or not FBS 2\% (v/v)), were monitored. Various techniques were used in parallel. TEM provided information about the core size, shape, and agglomeration state of the AgNPs. UV-vis spectroscopy made it possible to follow the surface plasmon resonance peak (SPR) of the AgNPs. In addition, the hydrodynamic diameter was established by DLS, while the zeta potential was determined by ELS.

In its pure form, the Mesosilver ${ }^{\mathrm{TM}}$ suspension had a brown colour, with a strong absorption peak at a maximum wavelength $\left(\lambda_{\max }\right)$ of $396 \mathrm{~nm}$, as a result of plasmon resonance, characteristic of metal nanoparticles (Ashkarran et al., 2012; Gao et al., 2017) (Figure 1C). As observed in TEM images, the AgNPs were spherical (Figure 1A), with a diameter between 4 and $31 \mathrm{~nm}$ (Figure 1B). Their mean diameter was $12.0 \pm 4.1 \mathrm{~nm}$, while the hydrodynamic size distribution was multimodal, with a large peak between 10 and $300 \mathrm{~nm}$ and a diameter at the maximum peak of $79 \mathrm{~nm}$ (Table S1 and Figure 1D). The zeta potential at the intrinsic $\mathrm{pH}$ of the Mesosilver ${ }^{\mathrm{TM}}$ suspension $(\mathrm{pH}=7.3)$ was $-30.1 \pm 4.8 \mathrm{mV}$. The AgC suspension was uncoloured and exclusively composed of ionic silver with no AgNPs observed by TEM or UV-vis spectroscopy (data not shown). 
The modifications that occurred to the AgNPs, present in the Mesosilver ${ }^{\mathrm{TM}}$ suspension and diluted to a concentration of $3 \mu \mathrm{g} / \mathrm{mL}$ in the cell culture medium, containing or not $2 \%(\mathrm{v} / \mathrm{v})$ FBS, were regularly monitored for a 48-h contact period (Figure S2). In contact with the culture medium, the $\lambda_{\max }$ value at $\mathrm{t}=0$, initially $396 \mathrm{~nm}$ in pure form, increased slightly, reaching 402 and $408 \mathrm{~nm}$, with or without 2\% (v/v) FBS, respectively (Figure S2B and S2A). The absorbance of Mesosilver ${ }^{\mathrm{TM}}$ only slightly decreased after $24 \mathrm{~h}$ of exposure to the culture medium with $2 \%$ (v/v) FBS, which was accompanied by a redshift of $\lambda_{\max }$ from 402 to $416 \mathrm{~nm}$ (Figure S2B). There was little change in the hydrodynamic diameter distribution (Figure S2D), with a slight increase in the hydrodynamic diameter at the maximum peak from $79 \mathrm{~nm}$ at $\mathrm{t}=0$ to $91 \mathrm{~nm}$ at $\mathrm{t}$ $=48 \mathrm{~h}$ (Table S1). In contrast, there was a large decrease in the intensity of the Mesosilver ${ }^{\mathrm{TM}}$ absorbance peak around $400 \mathrm{~nm}$ over time in the culture medium without FBS (Figure S2A), which was associated with an increase in the hydrodynamic diameter at the maximum peak from $164 \mathrm{~nm}$ at $\mathrm{t}=0$ to $1,281 \mathrm{~nm}$ at $\mathrm{t}=48 \mathrm{~h}$ (Table S1, Figure S2C). The zeta potential changed, independently of the presence of FBS in the culture medium, becoming less negative, with values reaching $-9.2 \pm 0.2 \mathrm{mV}$ at $\mathrm{t}=0$ and $-13.5 \pm 0.3 \mathrm{mV}$ at $\mathrm{t}=48 \mathrm{~h}$ in the absence of FBS and $-9.0 \pm 1.0 \mathrm{mV}$ at $\mathrm{t}=0$ and $-9.7 \pm 0.4 \mathrm{mV}$ at $\mathrm{t}=48 \mathrm{~h}$, in the presence of FBS (Table S1).

\subsection{Determination of cell viability of Caco-2 and Caco-2/HT29-MTX cell cultures during repeated exposure to Mesosilver ${ }^{\mathrm{TM}}$ and AgC suspensions}

First, the effect of Mesosilver ${ }^{\mathrm{TM}}$ and AgC suspensions on cell viability in Caco-2 monocultures and Caco-2/HT29-MTX co-cultures in 24-well plates during 18 days of repeated exposure (i.e. every 2 days) was evaluated for a wide range of concentrations (0-12 $\mu \mathrm{g} / \mathrm{mL})$. Both Mesosilver ${ }^{\mathrm{TM}}$ and AgC induced a loss in cell viability, as measured using the AlamarBlue ${ }^{\circledR}$ assay, in a concentration-, time-, cell model-, and colloidal silver product-dependent manner. The AlamarBlue ${ }^{\circledR}$ assay estimates the oxidative metabolism of viable cells by converting a 
redox dye (resazurin) into a fluorescent end product (resorufin). Indeed, after 2 days of exposure, cell viability gradually and significantly decreased $(P<0.001$ or $P<0.0001)$ for both Mesosilver $^{\mathrm{TM}}$ and AgC at concentrations from $6 \mu \mathrm{g} / \mathrm{mL}$ in both monoculture and co-culture cell models (Figure 2). Early signs of loss of cell viability were also observed at $3 \mu \mathrm{g} / \mathrm{mL} \mathrm{AgC} \mathrm{for}$ Caco-2 cells $(P<0.0001$, Figure $2 B)$. A significant loss of cell viability was obtained $(P<0.01$ or $P<0.0001$ ) after 7 days of exposure, regardless of the cell model for both Mesosilver ${ }^{\mathrm{TM}}$ and AgC from concentrations of $3 \mu \mathrm{g} / \mathrm{mL}$, which was further confirmed $(P<0.0001)$ after 18 days of exposure; once again, a decrease in viability was observed for AgC only from $1 \mu \mathrm{g} / \mathrm{mL}$ in Caco-2 monocultures $(P<0.01$, Figure 2B) and Caco-2/HT29-MTX co-cultures $(P<0.05$ or $P$ $<0.01$, Figure 2D). Interestingly, a significant increase in metabolic activity occurred in the Caco-2/HT29-MTX co-culture after 7 and 18 days of exposure to a low concentration of Mesosilver $^{\mathrm{TM}}$ or AgC of $0.5 \mu \mathrm{g} / \mathrm{mL}(P<0.01$ or $P<0.0001$, Figure $2 \mathrm{C}$ and $2 \mathrm{D})$; this was also true for the Caco-2 monoculture treated with AgC at a concentration of 0.1 or $0.5 \mu \mathrm{g} / \mathrm{mL}(P<$ 0.01, Figure 2B).

Based on these results, further assays were carried out using Mesosilver ${ }^{\mathrm{TM}}$ and $\mathrm{AgC}$ at a restricted concentration range of $0.1,1$, and $3 \mu \mathrm{g} / \mathrm{mL}$. Impedance measurements were performed using the xCELLigence system for the Caco-2 monoculture and Caco-2/HT29-MTX co-culture. The xCELLigence system measures the electrical impedance of cells grown on electrodes in situ and in real time. The electrical impedance is displayed as the change in cell index (Figure 3), which provides information on the cell number and inherent morphological and adhesive characteristics of the cells (Solly et al., 2004). The repeated exposure of Caco-2 and Caco-2/HT29-MTX cells to Mesosilver ${ }^{\mathrm{TM}}$ or AgC had no visible influence on the cell index for concentrations of 0.1 and $1 \mu \mathrm{g} / \mathrm{mL}$. In contrast, for the highest concentration of $3 \mu \mathrm{g} / \mathrm{mL}$, the cell index gradually decreased to reach statistical significance $(P<0.001)$ after 5 days of 
exposure on monocultures (Figure 3A) or co-cultures (Figure 3B), with similar profiles for the two types of colloidal silver products. Finally, cell viability using the AlamarBlue ${ }^{\circledR}$ assay was measured for Caco-2 and Caco-2/HT29-MTX cells cultured on Transwells after 18 days of exposure (Figure 4A and 4D). For the Caco-2 monoculture, there was a significant and marked decrease in cell viability at $3 \mu \mathrm{g} / \mathrm{mL}$ Mesosilver ${ }^{\mathrm{TM}}$ and from $1 \mu \mathrm{g} / \mathrm{mL}$ AgC $(P<0.0001$, Figure 4A). For the Caco-2/HT29-MTX co-culture, the loss in metabolic activity occurred from 1 $\mu \mathrm{g} / \mathrm{mL}$, regardless of the colloidal silver-containing product, with $P<0.0001$ for AgC and $P<$ 0.01 for Mesosilver ${ }^{\mathrm{TM}}$ (Figure 4D).

\subsection{Determination of trans-epithelial electrical resistance in Caco-2 and Caco-2/HT29- MTX cell cultures during repeated exposure to Mesosilver $^{\mathrm{TM}}$ and AgC suspensions} The measurement of TEER is classically used to assess the intestinal barrier integrity and permeability (Brun et al., 2014; García-Rodríguez et al., 2018; Vila et al., 2018). Here, TEER was monitored in situ and in real time using the cellZScope system for Caco-2 and Caco2/HT29-MTX cells grown on Transwells and repeatedly exposed to Mesosilver ${ }^{\mathrm{TM}}$ and AgC at concentrations of 1 and $3 \mu \mathrm{g} / \mathrm{mL}$ for 18 days. For the Caco-2 monoculture, a significant decrease in TEER $(P<0.05)$ was observed for Mesosilver ${ }^{\mathrm{TM}}$ at $3 \mu \mathrm{g} / \mathrm{mL}$ and AgC from $1 \mu \mathrm{g} / \mathrm{mL}$ (Figure 4B and 4C). In contrast, TEER was not impaired by the repeated exposure of the Caco2/HT29-MTX co-culture to MesosilverTM (Figure 4E) or AgC (Figure 4F). A slight and transient increase in TEER was only recorded between the $11^{\text {th }}$ and $13^{\text {th }}$ day of exposure for AgC at $3 \mu \mathrm{g} / \mathrm{mL}(P<0.05$, Figure $4 \mathrm{~F})$. 


\subsection{Determination of silver uptake and translocation in Caco-2 and Caco-2/HT29-MTX cell cultures after repeated exposure to Mesosilver ${ }^{\mathrm{TM}}$ and AgC suspensions}

Silver uptake by Caco-2 and Caco-2/HT29-MTX cells, after 18 days of repeated exposure to Mesosilver $^{\mathrm{TM}}$ or $\mathrm{AgC}$ at a concentration of $3 \mu \mathrm{g} / \mathrm{mL}$, was monitored by CytoViva ${ }^{\mathrm{TM}}$ hyperspectral imaging (Figure 5). Regardless of the cell model, discrete silver spots, consisting of AgNPs and/or Ag colloids, were distributed within the cell layer, with slightly preferential accumulation at the basolateral side, in close vicinity to the Transwell surface (Figure 5). Highresolution chemical imaging using HIM-SIMS was performed on the Caco-2 monoculture to gain further insight into the intracellular localisation of silver. The elemental distribution of ${ }^{107} \mathrm{Ag}^{+}$and ${ }^{12} \mathrm{C}^{14} \mathrm{~N}^{-}$in the cells is shown in Figure 6. The distribution of the ${ }^{12} \mathrm{C}^{14} \mathrm{~N}^{-}$cluster was chosen as a cell "fingerprint”. The intracellular presence of Ag was observed for both Mesosilver $^{\mathrm{TM}}$ and AgC (Figure 6). In addition to CytoViva ${ }^{\mathrm{TM}}$ and HIM-SIMS imaging, demonstrating silver uptake by intestinal epithelial cells, ICP-MS was carried out to evaluate silver translocation from the apical to basolateral compartments in Caco-2 monocultures and Caco-2/HT29-MTX co-cultures after the 18 days of exposure to MesosilverTM or AgC at 3 $\mu \mathrm{g} / \mathrm{mL}$ (Figure 7A and 7C and Figure 7B and 7D, respectively). Silver concentrations were measured by ICP-MS in the apical (Figure 7A and 7B) and basolateral (Figure 7C and 7D) media. The silver concentration was close to $1000 \mathrm{ng} / \mathrm{mL}$ in the apical medium and between 1 and $2 \mathrm{ng} / \mathrm{mL}$ in the basolateral medium, regardless of the colloidal silver product and cell model (Figure 7). Overall, these results imply that the silver present in the Mesosilver ${ }^{\mathrm{TM}}$ and AgC products was internalized and able to cross the epithelial barrier of the Caco-2 and Caco2/HT29-MTX cells, although it was not possible at this stage to determine in what form (i.e. AgNPs and/or ionic silver). In parallel, immunofluorescence staining of mucus in the Caco2/HT29-MTX cells was performed using the anti-MUC5AC antibody. Mucus did not form a uniform layer over the cell surface, but rather showed a patchy structure for untreated cells 
(Figure S3C), as well as cells repeatedly exposed to Mesosilver ${ }^{\mathrm{TM}}$ and AgC (Figure S3D and S3E).

\subsection{Evaluation of genotoxicity induced by Mesosilver ${ }^{\mathrm{TM}}$ and AgC suspensions on proliferative Caco-2 cells}

The presence of DNA double-strand breaks (DSBs) was examined in proliferating Caco-2 cells acutely exposed for 1,6 , or $24 \mathrm{~h}$ at concentrations of $0.1,1$, and $3 \mu \mathrm{g} / \mathrm{mL}$ to evaluate whether Mesosilver ${ }^{\mathrm{TM}}$ and AgC products are potential genotoxic agents. The presence of phosphorylated H2AX ( $\gamma \mathrm{H} 2 \mathrm{AX})$, a classic marker for DNA DSBs, was therefore studied by immunofluorescence. All results are presented in Table 1 and representative images obtained after $6 \mathrm{~h}$ of treatment at $1 \mu \mathrm{g} / \mathrm{mL}$ are shown in Figure S4. Cells exposed to $500 \mathrm{fM}$ calicheamicin were used as a positive control.

No genotoxic effect occurred after treatment with either colloidal silver product at $0.1 \mu \mathrm{g} / \mathrm{mL}$ or $1 \mathrm{~h}$ of treatment (Table 1). However, $\gamma \mathrm{H} 2 \mathrm{AX}$ intensity significantly increased after $6 \mathrm{~h}$ of exposure to Mesosilver ${ }^{\mathrm{TM}}(P<0.05)$ or $\mathrm{AgC}(P<0.0001)$ at $1 \mu \mathrm{g} / \mathrm{mL}$ (Figure S4 and Table 1$)$. The percentage of $\gamma \mathrm{H} 2 \mathrm{AX}$-positive cells was significantly higher for AgC than Mesosilver ${ }^{\mathrm{TM}}$ ( $P<0.001$ ), with $31.0 \pm 4.2 \%$ versus $16.0 \pm 3.1 \%$, respectively (vs $4.4 \pm 1.4 \%$ for untreated cells), suggesting higher genotoxicity of the AgC suspension. This was confirmed following 24 $\mathrm{h}$ of treatment at $1 \mu \mathrm{g} / \mathrm{mL}$ : at this timepoint, exposure to AgC induced cytotoxicity, whereas Mesosilver $^{\mathrm{TM}}$ exposure induced genotoxicity $(21.1 \pm 5.1 \%$ positive cells, $P<0.0001)$ (Table 1). For the highest concentration of $3 \mu \mathrm{g} / \mathrm{mL}$, more deleterious effects were once again observed for AgC than Mesosilver ${ }^{\mathrm{TM}}$ : after $1 \mathrm{~h}$, exposure to AgC induced genotoxicity that resulted in cytotoxicity after 6 or 24 h of exposure, whereas Mesosilver ${ }^{\mathrm{TM}}$ induced genotoxicity at $6 \mathrm{~h}$ (41.5 
$\pm 5.5 \%$ positive cells, $P<0.0001$ ), which was further associated with cytotoxicity after $24 \mathrm{~h}$ of treatment (Table 1).

\section{Discussion}

Given the growing interest in the antimicrobial properties of AgNPs and/or ionic silver, numerous colloidal silver products are currently being marketed for a wide range of health and disinfectant applications. In particular, dietary supplements advertised as immune boosters can easily be found in the US and Europe, even though silver no longer appears in the list of authorized vitamins and minerals in Europe. Toxicity studies have mainly focused on commercially available or laboratory-synthesized AgNPs tested at high unrealistic concentrations, up to $100 \mu \mathrm{g} / \mathrm{mL}$ (Georgantzopoulou et al., 2016; Saez-Tenorio et al., 2019; Williams et al., 2016), which are not representative of the ingested forms present in such dietary supplements. Indeed, the structural and physico-chemical characteristics of "real” AgNPs, such as concentration, particle size distribution, and/or interfacial properties, may differ from those of model AgNPs. Few studies have characterized the presence of AgNPs in colloidal silver products (Cascio et al., 2015; De Leersnyder et al., 2020; Reed et al., 2014; Rogers et al., 2020; Rong et al., 2018) and, furthermore, little is known about their fate, behaviour, or toxicity in the gastro-intestinal tract (Reed et al., 2014; Rogers et al., 2020; Rong et al., 2018).

The aim of the present study was to compare the physico-chemical properties of two colloidal silver products, Mesosilver ${ }^{\mathrm{TM}}$, produced by Purest Colloid in US (Farmen et al., 2012; Reed et al., 2014; Rong et al., 2018) and AgC marketed in France, and to assess their respective effects in vitro using realistic scenarios that mimic human exposure (i.e. low dose and repeated exposure). First, the physico-chemical properties of the AgNPs present in Mesosilver ${ }^{\mathrm{TM}}$ in its 
pure form were assessed. The AgNPs were spherical with a core diameter deduced from TEM analysis, of approximately $12 \mathrm{~nm}$, a hydrodynamic diameter, measured by DLS, of $33 \mathrm{~nm}$, and a negative zeta potential of $-30 \mathrm{mV}$, in accordance with published data (Rong et al., 2018). In the aforementioned study, the authors found $10.6 \%$ of silver as dissolved silver (ionic silver), whereas the rest was present as AgNPs (Rong et al., 2018). This is lower than the $22 \%$ and $46 \%$ values reported by Farmen et al. (2012) and Rogers et al. (2018) respectively. These discrepancies are likely explained by differences in the measurement methods and preparation of the samples. In contrast to Mesosilver ${ }^{\mathrm{TM}}$, the AgC suspension was only composed of ionic silver (i.e. no AgNPs detected), confirming the high variability in the relative percentage of particulate vs. soluble silver, observed among drinkable commercial colloidal silver-containing products (Cascio et al., 2015) and later on a broader range of consumer products advertised to contain colloidal silver (Rogers et al., 2018).

UV-visible spectroscopy was complementarily used to identify the presence of metallic AgNPs in the Mesosilver ${ }^{\mathrm{TM}}$ suspension. An absorption peak at $396 \mathrm{~nm}\left(\lambda_{\max }\right)$ was detected, corresponding to a size of the AgNPs of approximately $10 \mathrm{~nm}$ (Paramelle et al., 2014), in accordance with published data (Rogers et al., 2018). As interactions of AgNPs with their environment can lead to major physico-chemical modifications with subsequent modulation of their toxicity (Durán et al., 2015), the stability of AgNPs present in Mesosilver ${ }^{\mathrm{TM}}$ was evaluated in the cell culture medium used for the further assessment of their toxicological impact in vitro. In the presence of FBS, a relatively small redshift of $\lambda_{\max }$ of $20 \mathrm{~nm}$ was observed, suggesting the binding of biomolecules to AgNPs (Ashkarran et al., 2012; Burcza et al., 2015); such a biomolecular corona around the AgNPs may be involved in the protective role exerted by FBS. 
As colloidal silver is consumed orally, the first barrier to exposure is the gastrointestinal tract. Two in vitro gut models, a Caco-2 monoculture and a Caco-2/HT29-MTX co-culture, were thus used to evaluate the toxicological impact of Mesosilver ${ }^{\mathrm{TM}}$ and $\mathrm{AgC}$ suspensions. AgNPs and/or ionic silver are known to induce interference with a large number of viability assays (Mello et al., 2020; Riaz Ahmed et al., 2017). Therefore, the resazurin-based AlamarBlue ${ }^{\circledR}$ assay, reported to be a non-interfering method (Mello et al., 2020), was chosen to evaluate the cytotoxicity of Mesosilver ${ }^{\mathrm{TM}}$ and AgC. A loss in cell viability was observed for both Mesosilver ${ }^{\mathrm{TM}}$ and AgC in Caco-2 monocultures and Caco-2/HT29-MTX co-cultures in a concentration-dependent manner; for the 24-well culture, time-dependent effects were also found with increased cytotoxicity after repeated exposure. Despite the different culture systems used, the cytotoxicity profiles in the 0.1 to $3 \mu \mathrm{g} / \mathrm{mL}$ range were similar. However, for the 3 $\mu \mathrm{g} / \mathrm{mL}$ concentration, Caco-2 and Caco-2/HT29-MTX cells cultured in Transwells and repeatedly exposed to Mesosilver ${ }^{\mathrm{TM}}$ or AgC for 18 days were less sensitive than those cultured in 24-well plates, probably due to differences in cell differentiation. For a low concentration of $0.5 \mu \mathrm{g} / \mathrm{mL}$, there was an increase in metabolic activity after 7 or 18 days of treatment of Caco2/HT29-MTX cells with Mesosilver ${ }^{\mathrm{TM}}$ or AgC (also seen for AgC in Caco-2 cells). This ability to stimulate cell growth at low (nano)silver concentrations, or "hormetic effect" (Iavicoli et al., 2018), is in accordance with published results on synthetic AgNPs in Caco-2 cells after shortterm exposure (Chen et al., 2016). Comparison of the cytotoxicity induced by the colloidal silver products showed AgC to undoubtedly have more deleterious effects than Mesosilver ${ }^{\mathrm{TM}}$, as seen in the 24-well plate and Transwell culture systems. The presence of $\gamma \mathrm{H} 2 \mathrm{AX}$ was thus studied as a classic marker for DNA DSBs and genotoxicity to further the analysis and explain the observed cytotoxicity. For a given concentration and exposure time, $\gamma \mathrm{H} 2 \mathrm{AX}$ levels were higher for AgC- than Mesosilver ${ }^{\mathrm{TM}}$-exposed Caco-2 cells. These differences undoubtedly originate from the predominance of the ionic form of silver in the AgC suspension, generally 
described to be the main driver for silver toxicity (De Matteis et al., 2015; van der Zande et al., 2016), although several studies have reported specific AgNP-mediated toxic effects (Arai et al., 2015; Garcia-Reyero et al., 2014). Overall, a loss of viability was observed for differentiated Caco-2 cells, raising the issue of the toxicity of chronic exposure to colloidal silver, and proliferating Caco-2 cells showed increased levels of $\gamma \mathrm{H} 2 \mathrm{AX}$, suggesting a genotoxic effect, as recently reviewed (Hadrup et al., 2020).

Real-time cellZScope measurements of Caco-2 cells repeatedly exposed to Mesosilver ${ }^{\mathrm{TM}}$ for 18 days showed a concentration- and time-dependent decrease in TEER, as an indicator of progressive intestinal barrier impairment. In contrast, the same TEER alterations were obtained at 1 and $3 \mu \mathrm{g} / \mathrm{mL}$ of AgC, reinforcing the more deleterious impact of this 100\% ionic-silver containing product. Interestingly, exposure of the Caco-2/HT29-MTX co-culture to Mesosilver $^{\mathrm{TM}}$ or AgC did not induce any marked changes in TEER when using the 1 and 3 $\mu \mathrm{g} / \mathrm{mL}$ concentrations, suggesting that intestinal barrier integrity remained unaffected under these conditions, even though a loss in cell viability and a decrease in the cell index were observed. A similar trend of a decrease in cell viability without TEER changes was previously described for a Caco-2/HT29 mucus-secreting cell model exposed to synthetic AgNPs (SaezTenorio et al., 2019). One possible explanation is that mucus compensates, at least to some extent, for intestinal barrier alterations, as it was shown to contribute to TEER in HT29-MTX cells (Pontier et al., 2001). Due to the multilayer conformation of Caco-2/HT29-MTX cells (Figure S3B), it is also possible that cell mortality occurred without affecting intestinal barrier integrity, contrary to the Caco-2 monolayer (Figure S3A).

Concerning the influence of the cell model and the role of mucus, no striking differences in terms of cell viability were observed between Caco-2 and Caco-2/HT29-MTX cells, the key 
driver rather being the type of colloidal silver product. Due to its physical and chemical properties, mucus may trap dietary inorganic nanoparticles, such as AgNPs, thereby decreasing their toxicity to the host or, on the contrary, inducing high local accumulation with subsequent increased toxicity (Gillois et al., 2018). To date, few in vitro studies using intestinal cell models have considered mucus in the toxicological assessment of AgNPs and were limited to shortterm exposure conditions. In the study of Georgantzopoulou et al. (2016), Caco-2TC7/HT29MTX (90/10) cells were acutely exposed to synthetic AgNPs (10-100 $\mu \mathrm{g} / \mathrm{mL})$ for $24 \mathrm{~h}$. The mucus layer was able to trap 200-nm AgNPs, thus reducing their interaction with the cellular membrane and resulting in lower levels of toxicity, oxidative stress, IL-8 release, and proteomic alterations than for 20-nm AgNPs and silver nitrate, used as a control (Georgantzopoulou et al., 2016). More recently, Caco-2/HT29-MTX (75/25) cells were acutely exposed to pristine vs in vitro digested lipoic acid- and citrate-coated 50-nm AgNPs (250-2500 $\mu \mathrm{g} / \mathrm{mL})$ for $24 \mathrm{~h}$. Exposure to increasing concentrations of AgNPs resulted in a concentration-dependent increase of total Ag and AgNP content in the cellular fractions, with lower levels observed for digested AgNPs relative to their pristine counterparts. Confocal microscopy imaging showed clusters of silver or AgNPs mainly localized to the cell cytoplasm and, to some extent, the nucleus (Abdelkhaliq et al., 2020). Moreover, Saez-Tenorio et al. (2019) described a time-dependent increase in cellular uptake and internalization after exposure of Caco-2/HT29 cells to small (approximately $5 \mathrm{~nm}$ ) laboratory-synthesized AgNPs. After $24 \mathrm{~h}$ of exposure, most of the AgNPs were embedded in the mucus layer and at the end of the exposure period (96 h), a higher number of AgNPs was able to cross the mucus barrier and enter the cells (Saez-Tenorio et al., 2019). To gain further insights of the role of mucus in our conditions (commercial colloidal silver products, low doses, Caco-2/HT29-MTX cell model, repeated exposure), immunofluorescence staining of mucus was performed using the anti-MUC5AC antibody, as MUC5AC is the major gel-forming mucin produced by HT29-MTX cells (Lesuffleur et al., 
1993). Mucus did not form a uniform layer over the cell surface, but rather a patchy structure, as observed by confocal microscopy. This observation is in agreement with those of previous studies in which mucus patches were visualised in HT29-MTX cell layers (Coïc et al., 2012; Etzold et al., 2014; Radziwill-Bienkowska et al., 2017; Sperandio et al., 2013; Talbot et al., 2018), Caco-2/HT29-MTX co-cultures (70/30) (Dorier et al., 2017) and Caco-2/HT29 cocultures at varying ratios of 70/30, 80/20, and 90/10 with no differences in mucus secretion or distribution (García-Rodríguez et al., 2018). However, it was also reported that mucus secreted by Caco-2/HT29-MTX co-cultures (90/10) formed a mucus layer that completely covered the cell surface (Mahler et al., 2009). These discrepancies stress the necessity of examining the mucus when HT29-MTX cells are used for the toxicological assessment of AgNPs and other dietary inorganic nanoparticles. After repeated exposure to Mesosilver ${ }^{\mathrm{TM}}$ or AgC, confocalmicroscopy based qualitative inspection showed that mucus secretion remained unchanged in repeatedly-exposed cells relative to untreated cells, as previously reported for $\mathrm{TiO}_{2}$ nanoparticles (Dorier et al., 2017). Due to its patchy structure, the mucus was probably unable to exert its trapping properties and thus mitigate the deleterious effects of Mesosilver ${ }^{\mathrm{TM}}$ or AgC on Caco-2 cells. This is why both the Caco-2 and Caco-2/HT29-MTX cell models exhibited comparable silver translocation, albeit to only a slight extent (between 0.09 and $0.20 \%$ of apical silver content), as measured by ICP-MS in the basolateral compartment at the end of the repeated treatment with Mesosilver ${ }^{\mathrm{TM}}$ or AgC. These findings differ from those reported by Vila et al. (2018), who found no silver translocation in Caco-2 cells after $24 \mathrm{~h}$ of acute exposure to 1 to $50 \mu \mathrm{g} / \mathrm{mL}$ of synthetic AgNPs. However, in the study reported by Imai et al. (2017) on Caco-2 cells acutely exposed to AgNPs at $5 \mu \mathrm{g} / \mathrm{mL}, 0.28 \%$ and $0.22 \%$ of silver transported to the basolateral side were measured for citrate-ligand and lipoic-acid capped AgNPs, respectively (vs $0.27 \%$ for ionic silver). Interestingly, in the aforementioned study, the amount of silver found in the basolateral medium was markedly lower when the cells were treated with 
AgNPs or ionic silver at $4^{\circ} \mathrm{C}$, suggesting active transport (Imai et al., 2017). Abdelkhaliq et al. (2020) obtained values below 0.1\% for the translocation of either pristine or digested AgNPs through acutely-exposed Caco-2/HT29-MTX cells, either as total Ag or AgNPs. This is of the same order of magnitude as our results, despite different products and exposure regimes.

TEM was used as a first approach to visualize internalized AgNPs to support these findings on silver uptake and fate in vitro, but no clear presence of these particles was detected inside the cells, probably due to the granulated nature of the cell cytoplasm (data not shown). Dark-field hyperspectral imaging (CytoViva ${ }^{\mathrm{TM}}$ ) and high-resolution SIMS-based chemical imaging are powerful techniques that are increasingly used to investigate the distribution of NPs and chemical elements within biological matrices. CytoViva ${ }^{\mathrm{TM}}$ hyperspectral imaging was thus performed on Caco-2 and Caco-2/HT29-MTX cells repeatedly exposed to Mesosilver ${ }^{\mathrm{TM}}$ or AgC. CytoViva ${ }^{\mathrm{TM}}$ is a high contrast optical dark-field system , used in the nanotoxicology field for imaging $\mathrm{TiO}_{2}$ NPs (Konstantinova et al., 2017) and, more recently, AgNPs (Fizeşan et al., 2019; Mehennaoui et al., 2018). Nanoparticles and other light-scattering objects appear as bright features on a dark background; thus, fluorescent labelling of NPs, which could modify their physico-chemical properties, is not required. Complementarily to CytoViva ${ }^{\mathrm{TM}}$, highresolution chemical imaging was used on the same repeatedly-exposed samples; only Caco-2 cells were considered. Helium Ion Microscopy (HIM, ZEISS, Peabody, USA) consists of scanning the sample with a finely focussed $\mathrm{He}+$ ion beam of sub-nm resolution and detecting secondary electrons to generate images (Hlawacek and Gölzhäuser, 2016). In contrast to conventional Scanning Electron Microscopy (SEM), which uses an electron beam to scan the sample, HIM provides better contrast details due to smaller beam-sample interaction volumes, a better depth of field, and the possibility to image insulating samples without prior deposition of a conductive film. In addition, the HIM used for this study was equipped with a Secondary 
Ion Mass Spectrometer (SIMS) system developed by LIST, Luxembourg (Dowsett and Wirtz, 2017; Wirtz et al., 2019). The integrated HIM-SIMS instrument allows the acquisition of both high-resolution structural information and elemental/chemical information from the same field of view. It has been successfully applied to imaging a lithium titanate and magnesium oxide NP mixture (Dowsett and Wirtz, 2017) and correlating the morphology and composition of AgNPs (Fizeşan et al., 2019). In the present study, the CytoVivaTM and HIM-SIMS results converged on the cell uptake and internalization of silver (AgNPs and/or ionic silver) for both colloidal silver products and cell models, which may be influenced by the formation and nature of the biomolecular corona around AgNPs (Barbalinardo et al., 2018; Monteiro-Riviere et al., 2013).

In conclusion, the results of this study demonstrate that differences in the relative percentage of particulate (AgNPs) vs. soluble silver (ionic silver) in commercially available colloidal silver products, here Mesosilver ${ }^{\mathrm{TM}}$ and AgC, influence their toxicological impact in vitro on Caco-2 and Caco-2/HT29-MTX intestinal cell models, under realistic conditions that mimic human exposure, with low doses (0.1-12 $\mu \mathrm{g} / \mathrm{mL})$ and a repeated exposure regimen (every two days for 18 days). The most striking effects, including cytotoxicity and intestinal barrier impairment on differentiated Caco-2 cells, and genotoxicity on proliferating Caco-2 cells, were observed with the commercial product containing only ionic silver (AgC). Due to its patchy structure, the presence of mucus on intestinal cells in the Caco-2/HT29-MTX co-culture model only slightly mitigated these effects, underlining the necessity of examining mucus when HT29-MTX cells are used for the toxicological assessment of dietary inorganic nanoparticles and other chemicals. Regardless of the cell model, silver uptake and intracellular localization, as shown by CytoViva ${ }^{\mathrm{TM}}$ and HIM-SIMS, and subsequent silver translocation, were similar for both colloidal silver products. These findings demonstrate that high-resolution (chemical) imaging is a powerful approach to provide novel insights into mechanisms behind nanoparticle toxicity. 
Beyond analytical developments for the in-depth characterization of silver forms in native colloidal-silver based consumer products and biological fluids and tissues after exposure, future studies are needed to explore their gut toxicity in physiologically relevant in vitro and in vivo models to better understand the potential human exposure risks posed by these consumer products, which are becoming a growing concern. 


\section{Author contributions}

MHR, VT, HR, and MMB conceived and designed the study. MHR and MMB obtained funding. KG, ML, JB, and VM performed and analysed the in vitro experiments on cell cultures. IF, CS, SC, and JNA prepared, performed, and analysed the high-resolution imaging experiments. KG, JV, and GM designed, performed, and analysed the genotoxicity experiments. HT and MHR designed, performed, and analysed the ICP-MS experiments. KG, CS, JNA, MHR, HR, and MMB wrote the manuscript. All authors contributed to the discussion and approved the final manuscript.

\section{Acknowledgements}

The authors would like to thank T. Lesuffleur (INSERM U938, Paris, France) for her generous gift of the HT29-MTX cells, and Anne Fernandez-Vidal (University of Toulouse, Toulouse, France) for helpful discussions. The authors also thank Jelena Lorvic for fruitful scientific collaboration, Carole La and Marion Rivoal from the Laboratoire de Planétologie et Géodynamique (LPG, UMR 6112) for help to perform the ICP-MS and Eric Gautron from the Institut des Matériaux Jean Rouxel (Nantes, France) for performing the TEM measurements.

\section{Funding}

This work was supported by INRAE (TRANSFORM/MICA/AlimH inter-division 2018 call, NanoStress project).

The work of LIST was financed by the FluoGut project, INTER/ANR/18/12545362.

\section{Disclosure of interest}

The authors report no conflicts of interest. 


\section{Bibliography}

Abdelkhaliq, A., van der Zande, M., Undas, A.K., Peters, R.J.B., Bouwmeester, H., 2020. Impact of in vitro digestion on gastrointestinal fate and uptake of silver nanoparticles with different surface modifications. Nanotoxicology 14, 111-126. https://doi.org/10.1080/17435390.2019.1675794

Arai, Y., Miyayama, T., Hirano, S., 2015. Difference in the toxicity mechanism between ion and nanoparticle forms of silver in the mouse lung and in macrophages. Toxicology 328, 84-92. https://doi.org/10.1016/j.tox.2014.12.014

Ashkarran, A.A., Ghavami, M., Aghaverdi, H., Stroeve, P., Mahmoudi, M., 2012. Bacterial effects and protein corona evaluations: Crucial ignored factors in the prediction of bioefficacy of various forms of silver nanoparticles. Chem. Res. Toxicol. 25, 1231-1242. https://doi.org/10.1021/tx300083s

Barbalinardo, M., Caicci, F., Cavallini, M., Gentili, D., 2018. Protein Corona Mediated Uptake and Cytotoxicity of Silver Nanoparticles in Mouse Embryonic Fibroblast. Small 14, 1801219. https://doi.org/10.1002/smll.201801219

Béduneau, A., Tempesta, C., Fimbel, S., Pellequer, Y., Jannin, V., Demarne, F., Lamprecht, A., 2014. A tunable Caco-2/HT29-MTX co-culture model mimicking variable permeabilities of the human intestine obtained by an original seeding procedure. Eur. J. Pharm. Biopharm. 87, 290-298. https://doi.org/10.1016/j.ejpb.2014.03.017

Bi, Y., Marcus, A.K., Robert, H., Krajmalnik-Brown, R., Rittmann, B.E., Westerhoff, P., Ropers, M.H., Mercier-Bonin, M., 2020. The complex puzzle of dietary silver nanoparticles, mucus and microbiota in the gut. J. Toxicol. Environ. Heal. - Part B Crit. Rev. 7404. https://doi.org/10.1080/10937404.2019.1710914 
Böhmert, L., Girod, M., Hansen, U., Maul, R., Knappe, P., Niemann, B., Weidner, S.M., Thünemann, A.F., Lampen, A., 2014. Analytically monitored digestion of silver nanoparticles and their toxicity on human intestinal cells. Nanotoxicology 8, 631-642. https://doi.org/10.3109/17435390.2013.815284

Böhmert, L., Niemann, B., Lichtenstein, D., Juling, S., Lampen, A., 2015. Molecular mechanism of silver nanoparticles in human intestinal cells. Nanotoxicology 9, 852-860. https://doi.org/10.3109/17435390.2014.980760

Bonner, W.M., Redon, C.E., Dickey, J.S., Nakamura, A.J., Sedelnikova, O.A., Solier, S., Pommier, Y., 2008. $\quad \gamma \mathrm{H} 2 \mathrm{AX}$ and cancer. Nat. Rev. Cancer. https://doi.org/10.1038/nrc2523

Brun, E., Barreau, F., Veronesi, G., Fayard, B., Sorieul, S., Chanéac, C., Carapito, C., Rabilloud, T., Mabondzo, A., Herlin-Boime, N., Carrière, M., 2014. Titanium dioxide nanoparticle impact and translocation through ex vivo, in vivo and in vitro gut epithelia. Part. Fibre Toxicol. 11, 13. https://doi.org/10.1186/1743-8977-11-13

Burcza, A., Gräf, V., Walz, E., Greiner, R., 2015. Impact of surface coating and foodmimicking media on nanosilver-protein interaction. J. Nanoparticle Res. 17, 1-15. https://doi.org/10.1007/s11051-015-3235-7

Cascio, C., Geiss, O., Franchini, F., Ojea-Jimenez, I., Rossi, F., Gilliland, D., Calzolai, L., 2015. Detection, quantification and derivation of number size distribution of silver nanoparticles in antimicrobial consumer products. J. Anal. At. Spectrom. 30, 1255-1265. https://doi.org/10.1039/c4ja00410h

Chen, N., Song, Z.-M., Tang, H., Xi, W.-S., Cao, A., Liu, Y., Wang, H., 2016. Toxicological Effects of Caco-2 Cells Following Short-Term and Long-Term Exposure to Ag Nanoparticles. Int. J. Mol. Sci. 17, 974. https://doi.org/10.3390/ijms17060974

Coïc, Y.M., Baleux, F., Poyraz, Ö., Thibeaux, R., Labruyere, E., Chretien, F., Sobhani, I., 
Lazure, T., Wyplosz, B., Schneider, G., Mulard, L., Sansonetti, P.J., Marteyn, B.S., 2012. Design of a specific colonic mucus marker using a human commensal bacterium cell surface domain. J. Biol. Chem. 287, 15916-15922. https://doi.org/10.1074/jbc.M111.310003

De Leersnyder, I., Rijckaert, H., De Gelder, L., Driessche, I. Van, Vermeir, P., Van Driessche, I., Vermeir, P., 2020. High variability in silver particle characteristics, silver concentrations, and production batches of commercially available products indicates the need for a more rigorous approach. Nanomaterials 10, 1-22. https://doi.org/10.3390/nano10071394

De Matteis, V., Ada Malvindi, M., Galeone, A., Brunetti, V., De Luca, E., Kote, S., Kshirsagar, P., Sabella, S., Bardi, G., Paolo Pompa, P., Malvindi, M.A., Galeone, A., Brunetti, V., De Luca, E., Kote, S., Kshirsagar, P., Sabella, S., Bardi, G., Pompa, P.P., 2015. Negligible particle-specific toxicity mechanism of silver nanoparticles: The role of Ag + ion release in the cytosol. Nanomedicine Nanotechnology, Biol. Med. 11, 731-739. https://doi.org/10.1016/j.nano.2014.11.002

Dorier, M., Béal, D., Marie-Desvergne, C., Dubosson, M., Barreau, F., Houdeau, E., HerlinBoime, N., Carriere, M., 2017. Continuous in vitro exposure of intestinal epithelial cells to E171 food additive causes oxidative stress, inducing oxidation of DNA bases but no $\begin{array}{lllll}\text { endoplasmic } & \text { reticulum } & \text { stress. } & \text { Nanotoxicology } & 11,\end{array}$ https://doi.org/10.1080/17435390.2017.1349203

Dowsett, D., Wirtz, T., 2017. Co-Registered in Situ Secondary Electron and Mass Spectral Imaging on the Helium Ion Microscope Demonstrated Using Lithium Titanate and Magnesium Oxide Nanoparticles. Anal. Chem. 89, 8957-8965. https://doi.org/10.1021/acs.analchem.7b01481

Durán, N., Silveira, C.P., Durán, M., Martinez, D.S.T., 2015. Silver nanoparticle protein corona 
and toxicity: A mini-review. J. Nanobiotechnology 13, 55. https://doi.org/10.1186/s12951-015-0114-4

Etzold, S., Kober, O.I., Mackenzie, D.A., Tailford, L.E., Gunning, A.P., Walshaw, J., Hemmings, A.M., Juge, N., 2014. Structural basis for adaptation of lactobacilli to gastrointestinal mucus. Environ. Microbiol. 16, 888-903. https://doi.org/10.1111/14622920.12377

Farmen, E., Mikkelsen, H.N., Evensen, Einset, J., Heier, L.S., Rosseland, B.O., Salbu, B., Tollefsen, K.E., Oughton, D.H., 2012. Acute and sub-lethal effects in juvenile Atlantic salmon exposed to low $\mu \mathrm{g} / \mathrm{L}$ concentrations of Ag nanoparticles. Aquat. Toxicol. 108, 7884. https://doi.org/10.1016/j.aquatox.2011.07.007

Fizeşan, I., Cambier, S., Moschini, E., Chary, A., Nelissen, I., Ziebel, J., Audinot, J.N., Wirtz, T., Kruszewski, M., Pop, A., Kiss, B., Serchi, T., Loghin, F., Gutleb, A.C., 2019. In vitro exposure of a 3D-tetraculture representative for the alveolar barrier at the air-liquid interface to silver particles and nanowires. Part. Fibre Toxicol. 16. https://doi.org/10.1186/s12989-019-0297-1

Gao, X., Topping, V.D., Keltner, Z., Sprando, R.L., Yourick, J.J., 2017. Toxicity of nano- and ionic silver to embryonic stem cells: A comparative toxicogenomic study. J. Nanobiotechnology 15, 31. https://doi.org/10.1186/s12951-017-0265-6

Garcia-Reyero, N., Kennedy, A.J., Escalon, B.L., Habib, T., Laird, J.G., Rawat, A., Wiseman, S., Hecker, M., Denslow, N., Steevens, J.A., Perkins, E.J., 2014. Differential effects and potential adverse outcomes of ionic silver and silver nanoparticles in vivo and in vitro. Environ. Sci. Technol. 48, 4546-4555. https://doi.org/10.1021/es4042258

García-Rodríguez, A., Vila, L., Cortés, C., Hernández, A., Marcos, R., 2018. Exploring the usefulness of the complex in vitro intestinal epithelial model Caco-2/HT29/Raji-B in nanotoxicology. Food Chem. Toxicol. 113, 162-170. 
https://doi.org/10.1016/j.fct.2018.01.042

Georgantzopoulou, A., Serchi, T., Cambier, S., Leclercq, C.C., Renaut, J., Shao, J., Kruszewski, M., Lentzen, E., Grysan, P., Eswara, S., Audinot, J.N., Contal, S., Ziebel, J., Guignard, C., Hoffmann, L., Murk, A.T.J., Gutleb, A.C., 2016. Effects of silver nanoparticles and ions on a co-culture model for the gastrointestinal epithelium. Part. Fibre Toxicol. 13, 9. https://doi.org/10.1186/s12989-016-0117-9

Gillois, K., Lévêque, M., Théodorou, V., Robert, H., Mercier-Bonin, M., 2018. Mucus : An Underestimated Gut Target for Environmental Pollutants and Food Additives. Microorg. Rev. 6, 1-18. https://doi.org/10.3390/microorganisms6020053

Hadrup, N., Sharma, A.K., Loeschner, K., Jacobsen, N.R., 2020. Pulmonary toxicity of silver vapours, nanoparticles and fine dusts: A review. Regul. Toxicol. Pharmacol. 115, 104690. https://doi.org/10.1016/j.yrtph.2020.104690

Hilgendorf, C., Spahn-Langguth, H., Regårdh, C.G., Lipka, E., Amidon, G.L., Langguth, P., 2000. Caco-2 versus Caco-2/HT29-MTX co-cultured cell lines: Permeabilities via diffusion, inside- and outside-directed carrier-mediated transport. J. Pharm. Sci. 89, 6375. https://doi.org/10.1002/(SICI)1520-6017(200001)89:1<63::AID-JPS7>3.0.CO;2-6

Hlawacek G, G.A., 2016. Helium Ion Microscopy. Springer.

Iavicoli, I., Leso, V., Fontana, L., Calabrese, E.J., 2018. Nanoparticle exposure and hormetic dose-responses: An update. Int. J. Mol. Sci. 19. https://doi.org/10.3390/ijms19030805

Imai, S., Morishita, Y., Hata, T., Kondoh, M., Yagi, K., Gao, J.Q., Nagano, K., Higashisaka, K., Yoshioka, Y., Tsutsumi, Y., 2017. Cellular internalization, transcellular transport, and cellular effects of silver nanoparticles in polarized Caco-2 cells following apical or basolateral exposure. Biochem. Biophys. Res. Commun. 484, 543-549. https://doi.org/10.1016/j.bbrc.2017.01.114

Juling, S., Niedzwiecka, A., Böhmert, L., Lichtenstein, D., Selve, S., Braeuning, A., 
Thünemann, A.F., Krause, E., Lampen, A., 2017. Protein Corona Analysis of Silver Nanoparticles Links to Their Cellular Effects. J. Proteome Res. 16, 4020-4034. https://doi.org/10.1021/acs.jproteome.7b00412

Konstantinova, V., Ibrahim, M., Lie, S.A., Birkeland, E.S., Neppelberg, E., Marthinussen, M.C., Costea, D.E., Cimpan, M.R., 2017. Nano-TiO2 penetration of oral mucosa: in vitro analysis using 3D organotypic human buccal mucosa models. J. Oral Pathol. Med. 46, 214-222. https://doi.org/10.1111/jop.12469

Larsen, P.B., Christensen, F., Jensen, K.A., Brinch, A., Mikkelsen, S.H., 2015. Exposure assessment of nanomaterials in consumer products. Danish Environ. Prot. Agency, Environ. Proj. No. 1636, 2015.

Lesuffleur, T., Porchet, N., Aubert, J.P., Swallow, D., Gum, J.R., Kim, Y.S., Real, F.X., Zweibaum, A., 1993. Differential expression of the human mucin genes MUC1 to MUC5 in relation to growth and differentiation of different mucus-secreting HT-29 cell subpopulations. J. Cell Sci. 106, 771-783.

Lichtenstein, D., Ebmeyer, J., Knappe, P., Juling, S., Böhmert, L., Selve, S., Niemann, B., Braeuning, A., Thünemann, A.F., Lampen, A., 2015. Impact of food components during in vitro digestion of silver nanoparticles on cellular uptake and cytotoxicity in intestinal cells. Biol. Chem. 396, 1255-1264. https://doi.org/10.1515/hsz-2015-0145

Lozoya-Agullo, I., Araújo, F., González-Álvarez, I., Merino-Sanjuán, M., González-Álvarez, M., Bermejo, M., Sarmento, B., 2017. Usefulness of Caco-2/HT29-MTX and Caco2/HT29-MTX/Raji B coculture models to predict intestinal and colonic permeability compared to Caco-2 monoculture. Mol. Pharm. 14, 1264-1270. https://doi.org/10.1021/acs.molpharmaceut.6b01165

Mahler, G.J., Shuler, M.L., Glahn, R.P., 2009. Characterization of Caco-2 and HT29-MTX cocultures in an in vitro digestion/cell culture model used to predict iron bioavailability. J. 
Nutr. Biochem. 20, 494-502. https://doi.org/10.1016/j.jnutbio.2008.05.006

Mehennaoui, K., Cambier, S., Serchi, T., Ziebel, J., Lentzen, E., Valle, N., Guérold, F., Thomann, J.S., Giamberini, L., Gutleb, A.C., 2018. Do the pristine physico-chemical properties of silver and gold nanoparticles influence uptake and molecular effects on Gammarus fossarum (Crustacea Amphipoda)? Sci. Total Environ. 643, 1200-1215. https://doi.org/10.1016/j.scitotenv.2018.06.208

Mello, D.F., Trevisan, R., Rivera, N., Geitner, N.K., Di Giulio, R.T., Wiesner, M.R., Hsu-Kim, H., Meyer, J.N., 2020. Caveats to the use of MTT, neutral red, Hoechst and Resazurin to measure silver nanoparticle cytotoxicity. Chem. Biol. Interact. 315. https://doi.org/10.1016/j.cbi.2019.108868

Monteiro-Riviere, N.A., Samberg, M.E., Oldenburg, S.J., Riviere, J.E., 2013. Protein binding modulates the cellular uptake of silver nanoparticles into human cells: Implications for in vitro to in vivo extrapolations? Toxicol. Lett. 220, 286-293. https://doi.org/10.1016/j.toxlet.2013.04.022

"Over-the-counter drug products containing colloidal silver ingredients or silver salts," Federal Register, 1999, 21 CFR Part 310, Rules and Regulations, FR Doc. 99-21253, Department of Health and Human Services, Food and Drug Administration, 44653.

Paramelle, D., Sadovoy, A., Gorelik, S., Free, P., Hobley, J., Fernig, D.G., 2014. A rapid method to estimate the concentration of citrate capped silver nanoparticles from UVvisible light spectra. Analyst 139, 4855-4861. https://doi.org/10.1039/c4an00978a

Pietroiusti, A., Bergamaschi, E., Campagna, M., Campagnolo, L., De Palma, G., Iavicoli, S., Leso, V., Magrini, A., Miragoli, M., Pedata, P., Palombi, L., Iavicoli, I., 2017. The unrecognized occupational relevance of the interaction between engineered nanomaterials and the gastro-intestinal tract: A consensus paper from a multidisciplinary working group. Part. Fibre Toxicol. https://doi.org/10.1186/s12989-017-0226-0 
Pontier, C., Pachot, J., Botham, R., Lenfant, B., Arnaud, P., 2001. HT29-MTX and Caco-2/TC7 monolayers as predictive models for human intestinal absorption: Role of the mucus layer. J. Pharm. Sci. 90, 1608-1619. https://doi.org/10.1002/jps.1111

Radziwill-Bienkowska, J.M., Robert, V., Drabot, K., Chain, F., Cherbuy, C., Langella, P., Thomas, M., Bardowski, J.K., Mercier-Bonin, M., Kowalczyk, M., 2017. Contribution of plasmid-encoded peptidase S8 (PrtP) to adhesion and transit in the gut of Lactococcus lactis IBB477 strain. Appl. Microbiol. Biotechnol. 101, 5709-5721. https://doi.org/10.1007/s00253-017-8334-1

Reed, R.B., Faust, J.J., Yang, Y., Doudrick, K., Capco, D.G., Hristovski, K., Westerhoff, P., 2014. Characterization of nanomaterials in metal colloid-containing dietary supplement drinks and assessment of their potential interactions after ingestion. ACS Sustain. Chem. Eng. 2, 1616-1624. https://doi.org/10.1021/sc500108m

Riaz Ahmed, K.B., Nagy, A.M., Brown, R.P., Zhang, Q., Malghan, S.G., Goering, P.L., 2017. Silver nanoparticles: Significance of physicochemical properties and assay interference on the interpretation of in vitro cytotoxicity studies. Toxicol. Vitr. 38, 179-192. https://doi.org/10.1016/j.tiv.2016.10.012

Rogakou, E.P., Nieves-Neira, W., Boon, C., Pommier, Y., Bonner, W.M., 2000. Initiation of DNA fragmentation during apoptosis induces phosphorylation of H2AX histone at serine 139. J. Biol. Chem. 275, 9390-9395. https://doi.org/10.1074/jbc.275.13.9390

Rogers, K.R., Henson, T.E., Navratilova, J., Surette, M., Hughes, M.F., Bradham, K.D., Stefaniak, A.B., Knepp, A.K., Bowers, L., 2020. In vitro intestinal toxicity of commercially available spray disinfectant products advertised to contain colloidal silver. Sci. Total Environ. 728, 138611. https://doi.org/10.1016/j.scitotenv.2020.138611

Rogers, K.R., Navratilova, J., Stefaniak, A., Bowers, L., Knepp, A.K., Al-Abed, S.R., Potter, P., Gitipour, A., Radwan, I., Nelson, C., Bradham, K.D., 2018. Characterization of 
engineered nanoparticles in commercially available spray disinfectant products advertised to contain colloidal silver. Sci. Total Environ. 619-620, 1375-1384. https://doi.org/10.1016/j.scitotenv.2017.11.195

Rong, H., Garg, S., Westerhoff, P., Waite, T.D., 2018. In vitro characterization of reactive oxygen species (ROS) generation by the commercially available Mesosilver ${ }^{\mathrm{TM}}$ dietary supplement. Environ. Sci. Nano 5, 2686-2698. https://doi.org/10.1039/c8en00701b

Saez-Tenorio, M., Domenech, J., García-Rodríguez, A., Velázquez, A., Hernández, A., Marcos, R., Cortés, C., 2019. Assessing the relevance of exposure time in differentiated Caco2/HT29 cocultures. Effects of silver nanoparticles. Food Chem. Toxicol. 123, 258-267. https://doi.org/10.1016/j.fct.2018.11.009

Solly, K., Wang, X., Xu, X., Strulovici, B., Zheng, W., 2004. Application of real-time cell electronic sensing (RT-CES) technology to cell-based assays. Assay Drug Dev. Technol. 2, 363-372. https://doi.org/10.1089/adt.2004.2.363

Sperandio, B., Fischer, N., Chevalier-Curt, M.J., Rossez, Y., Roux, P., Masselot, C.R., Sansonetti, P.J., 2013. Virulent shigella flexneri affects secretion, expression, and glycosylation of gel-forming mucins in mucus-producing cells. Infect. Immun. 81, 36323643. https://doi.org/10.1128/IAI.00551-13

Talbot, P., Radziwill-Bienkowska, J.M., Kamphuis, J.B.J., Steenkeste, K., Bettini, S., Robert, V., Noordine, M.L., Mayeur, C., Gaultier, E., Langella, P., Robbe-Masselot, C., Houdeau, E., Thomas, M., Mercier-Bonin, M., 2018. Food-grade TiO2 is trapped by intestinal mucus in vitro but does not impair mucin O-glycosylation and short-chain fatty acid synthesis in vivo: Implications for gut barrier protection. J. Nanobiotechnology 16, 53. https://doi.org/10.1186/s12951-018-0379-5

The Woodrow Wilson International Center. Consumer products inventory. . Accessed Apr 2016. http://www.nanotechproject.org/cpi/ 
Tulve, N.S., Stefaniak, A.B., Vance, M.E., Rogers, K., Mwilu, S., LeBouf, R.F., SchweglerBerry, D., Willis, R., Thomas, T.A., Marr, L.C., 2015. Characterization of silver nanoparticles in selected consumer products and its relevance for predicting children's potential exposures. Int. J. Hyg. Environ. Health 218, 345-357. https://doi.org/10.1016/j.ijheh.2015.02.002

Van der Zande, M., Undas, A.K., Kramer, E., Monopoli, M.P., Peters, R.J., Garry, D., Antunes Fernandes, E.C., Hendriksen, P.J., Marvin, H.J.P., Peijnenburg, A.A., Bouwmeester, H., 2016. Different responses of Caco-2 and MCF-7 cells to silver nanoparticles are based on highly similar mechanisms of action. Nanotoxicology 10, 1431-1441. https://doi.org/10.1080/17435390.2016.1225132

Vila, L., García-Rodríguez, A., Cortés, C., Marcos, R., Hernández, A., 2018. Assessing the effects of silver nanoparticles on monolayers of differentiated Caco-2 cells, as a model of intestinal barrier. Food Chem. Toxicol. 116, 1-10. https://doi.org/10.1016/j.fct.2018.04.008

Vila, L., Marcos, R., Hernández, A., 2017. Long-term effects of silver nanoparticles in caco-2 cells. Nanotoxicology 11, 771-780. https://doi.org/10.1080/17435390.2017.1355997

Wijnhoven, S.W.P., Peijnenburg, W.J.G.M., Herberts, C.A., Hagens, W.I., Oomen, A.G., Heugens, E.H.W., Roszek, B., Bisschops, J., Gosens, I., Van De Meent, D., Dekkers, S., De Jong, W.H., Van Zijverden, M., Sips, A.J.A.M., Geertsma, R.E., 2009. Nano-silver A review of available data and knowledge gaps in human and environmental risk assessment. Nanotoxicology. https://doi.org/10.1080/17435390902725914

Williams, K.M., Gokulan, K., Cerniglia, C.E., Khare, S., 2016. Size and dose dependent effects of silver nanoparticle exposure on intestinal permeability in an in vitro model of the human gut epithelium. J. Nanobiotechnology 14. https://doi.org/10.1186/s12951-016-0214-9

Wirtz, T., De Castro, O., Audinot, J.-N., Philipp, P., 2019. Imaging and Analytics on the Helium 
Ion Microscope. Annu. Rev. Anal. Chem. 12, 523-543. https://doi.org/10.1146/annurevanchem-061318-115457

Wu, W., Zhang, R., McClements, D.J., Chefetz, B., Polubesova, T., Xing, B., 2018. Transformation and Speciation Analysis of Silver Nanoparticles of Dietary Supplement in Simulated Human Gastrointestinal Tract. Environ. Sci. Technol. 52, 8792-8800. https://doi.org/10.1021/acs.est.8b01393 
Table 1. Proportion of $\gamma \mathrm{H} 2 \mathrm{AX}$-positive cells after exposure of proliferating Caco- 2 cells to Mesosilver $^{\mathrm{TM}}$ or AgC. Values correspond to the mean \pm SD of eight images for each condition. Values for the positive control with $500 \mathrm{fM}$ calicheamicin and untreated cells are given.

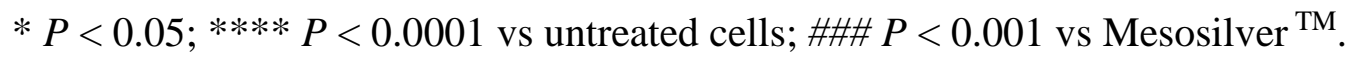

\begin{tabular}{|c|c|c|c|c|c|c|c|c|}
\hline \multirow{2}{*}{$\begin{array}{l}\text { Time } \\
\text { (h) }\end{array}$} & \multirow[b]{2}{*}{ Calichcamicin $500 \mathrm{fM}$} & \multirow[b]{2}{*}{ Untrcated } & \multicolumn{3}{|c|}{$\begin{array}{c}\text { Mesosilver } \\
(\mu \mathrm{g} / \mathrm{mL})\end{array}$} & \multicolumn{3}{|c|}{$\begin{array}{c}\Lambda \mathrm{gC} \\
(\mu \mathrm{g} / \mathrm{mL})\end{array}$} \\
\hline & & & 0.1 & 1 & 3 & 0.1 & 1 & 3 \\
\hline 1 & $98.0+2.0$ & $1.1+0.8$ & $3.5+2.2$ & $3.7+1.6$ & $2.9+1.0$ & $4.0+1.5$ & $0.9+0.6$ & $9.5+3.0$ \\
\hline 6 & & $4.4+1.4$ & $2.3+1.2$ & $16.0+3.2 *$ & $41.5+5.5$ ***** & $6.4+1.6$ & $31.0+4.2$ *****\#\#\# & Cytotoxicity \\
\hline 24 & & $4.4+1.9$ & $3.5+1.8$ & $21.1+5.1$ ***** & Cytotoxicity & $3.5+1.8$ & Cytotoxicity & Cytotoxicity \\
\hline
\end{tabular}




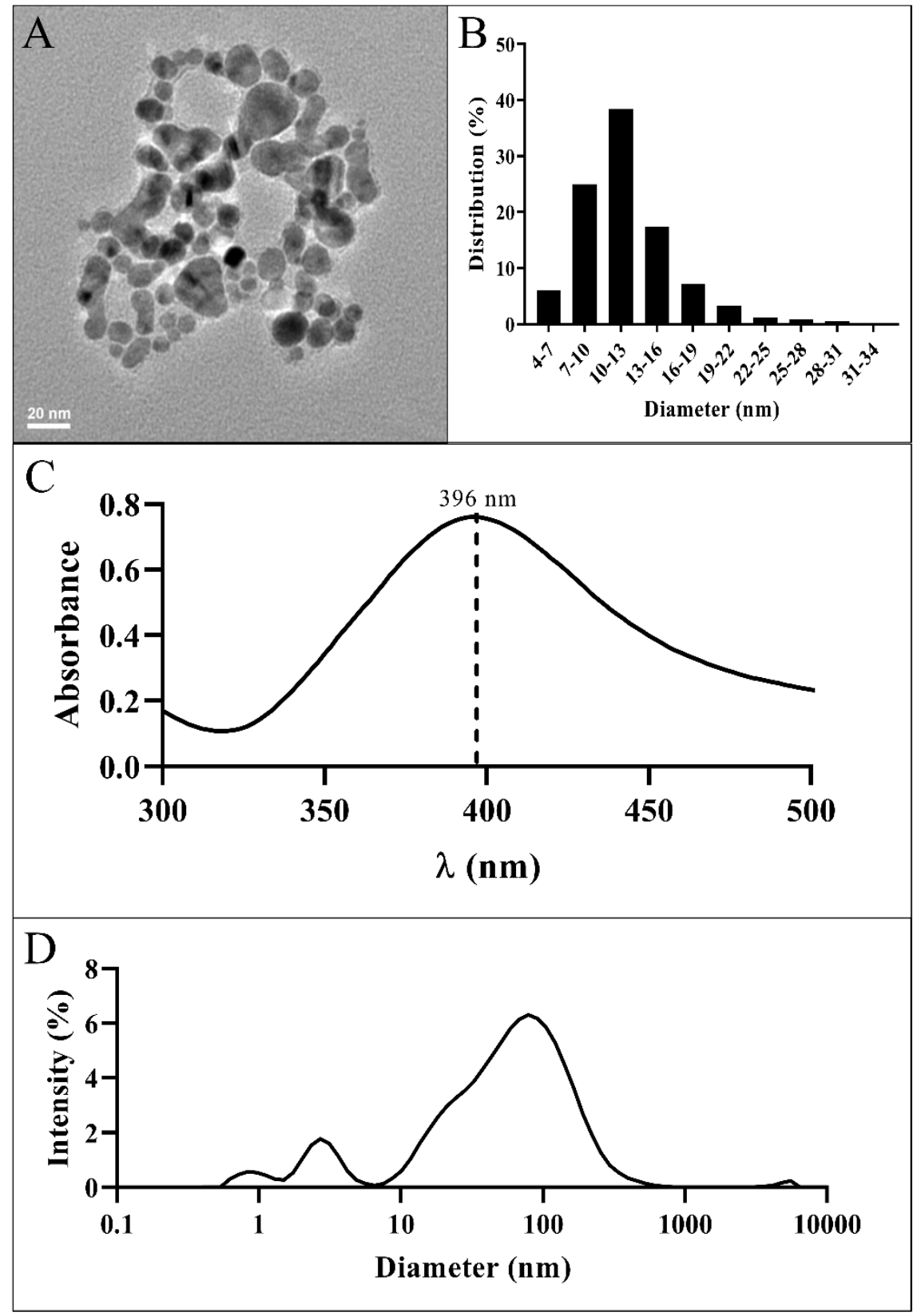

Figure 1. Physico-chemical characterization of commercial colloidal silver Mesosilver ${ }^{\mathrm{TM}}$ in its pure form. (A) Representative TEM image of AgNPs and (B) Core size distribution of AgNPs based on diameters measured on TEM images. (C) UV-vis spectrum with the maximum absorption wavelength $\left(\lambda_{\max }\right)$ labelled. (D) Hydrodynamic diameter distribution of AgNPs obtained from DLS measurements. 


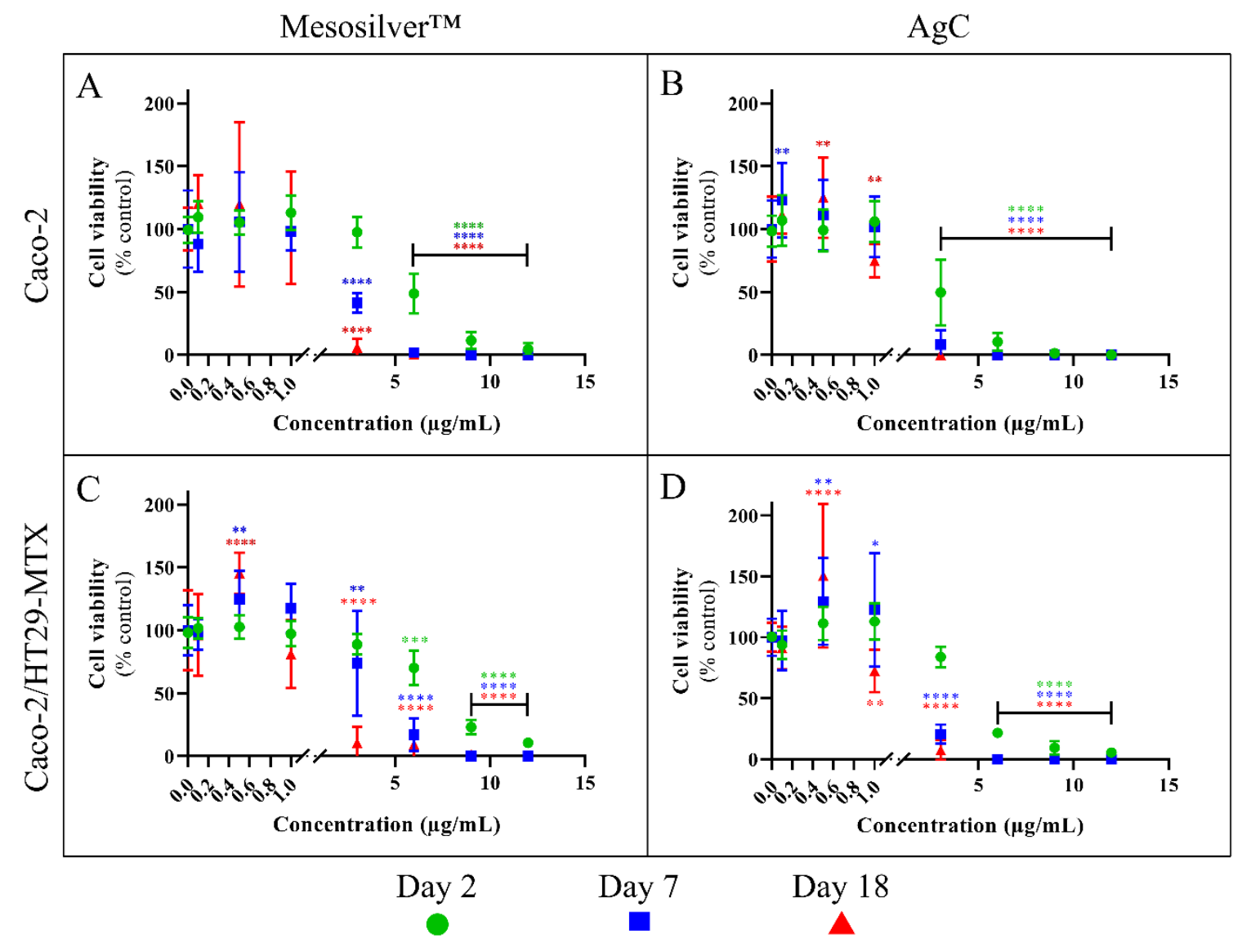

Figure 2. Effect of colloidal silver products on cell viability for $\operatorname{Mesosilver}^{\mathrm{TM}}(\mathrm{A}, \mathrm{C})$ and AgC (B,D) after 2, 7 and 18 days of repeated exposure in Caco-2 monoculture (A,B) and Caco2/HT29-MTX co-culture (C,D) in 24-well plates. Cell viability is expressed as the percentage of that of control (untreated cells). Significant differences from untreated cells are marked with asterisks (*P $<0.05$; ** $P<0.01$; *** $P<0.001$; **** $P<0.0001$ ). 


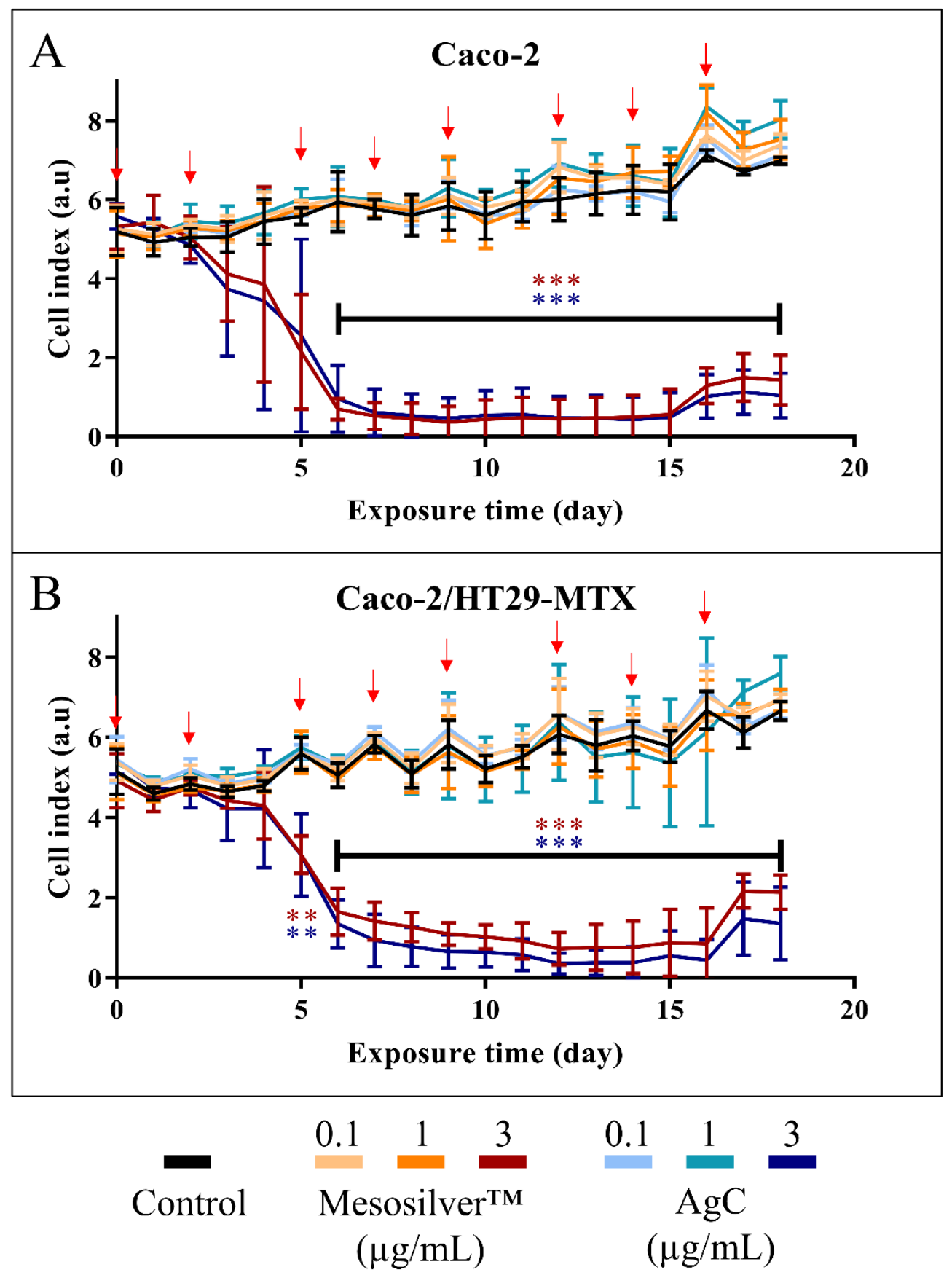

Figure 3. Changes in the cell index measured in real-time using the xCELLigence system. Caco-2 cells (A) or Caco-2/HT29-MTX cells (B) cultured in E-plates were exposed to Mesosilver ${ }^{\mathrm{TM}}$ or AgC at each medium refreshment (red arrow) every two days for 18 days. Significant differences from untreated cells are marked with asterisks (** $P<0.01$; *** $P<$ $0.001)$. 


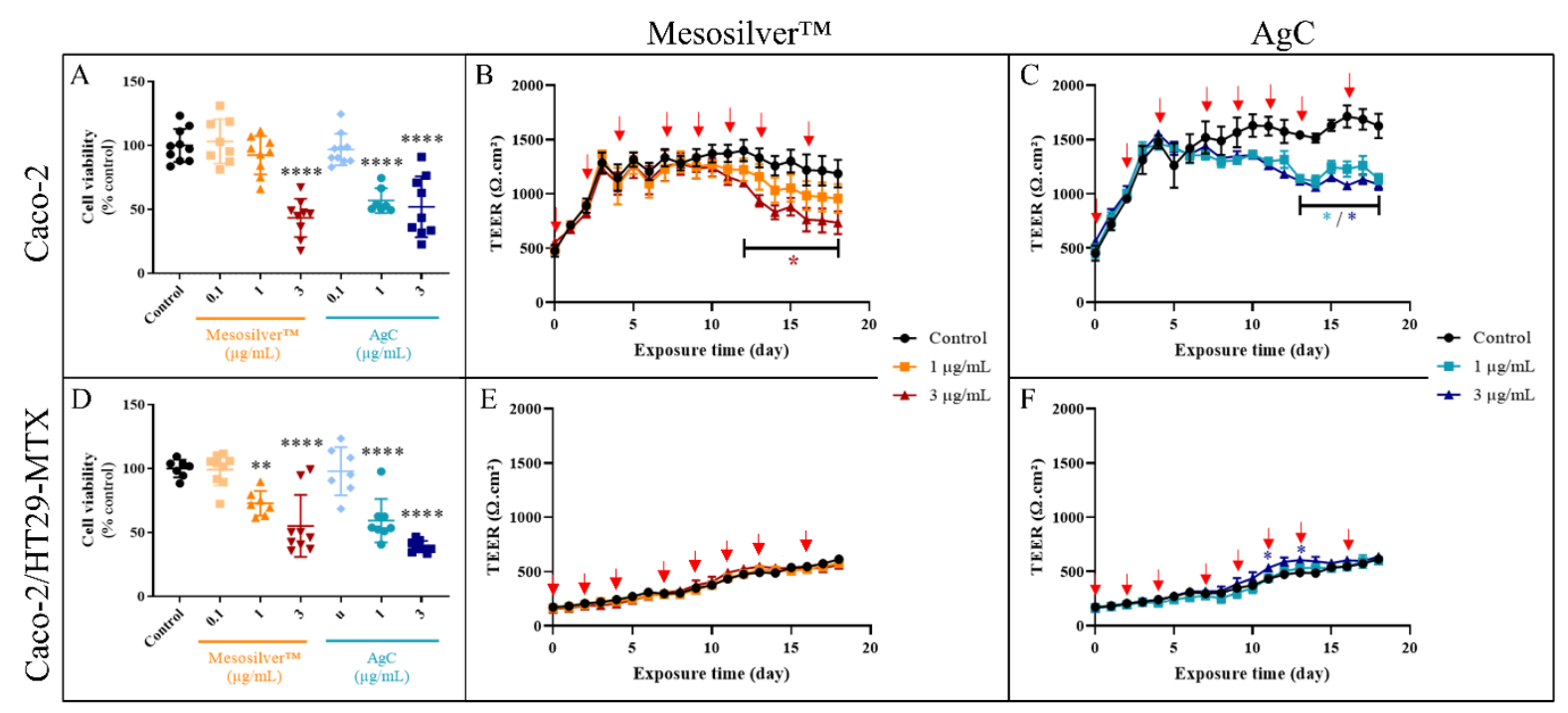

Figure 4. Cell viability after 18 days of repeated exposure to Mesosilver ${ }^{\mathrm{TM}}$ and AgC and changes in trans-epithelial electrical resistance (TEER). Cell viability, expressed as the percentage of that of control (untreated cells), was measured on Caco-2 monoculture (A) and Caco-2/HT29-MTX co-culture (D) in Transwells, at the end of the 18-day repeated exposure to Mesosilver ${ }^{\mathrm{TM}}$ or AgC. TEER was monitored in real-time using the cellZScope system on Caco2 cells (B,C) and Caco-2/HT29-MTX cells (E,F) exposed to Mesosilver ${ }^{\mathrm{TM}}$ or AgC. The culture medium was refreshed every two days for 18 days (red arrow). Significant differences from untreated cells are marked with asterisks ( ${ }^{*} P<0.05$; ** $P<0.01$; **** $\left.P<0.0001\right)$. 


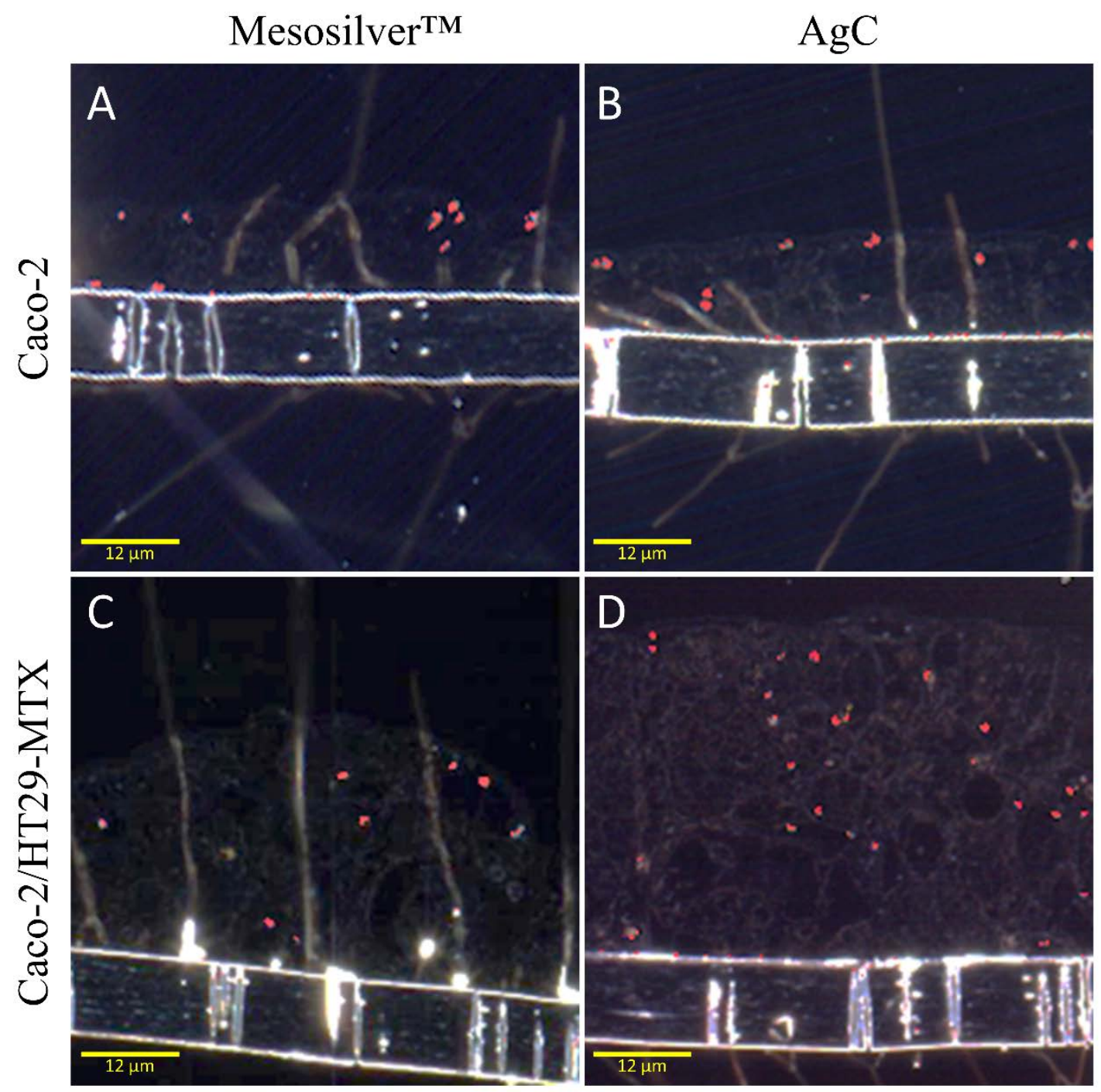

Figure 5. High-resolution dark-field microscopy images (CytoViva ${ }^{\mathrm{TM}}$ ) of Caco-2 cells $(\mathrm{A}, \mathrm{B})$ and Caco-2/HT29-MTX cells (C,D) repeatedly exposed to Mesosilver $^{\mathrm{TM}}(\mathrm{A}, \mathrm{C})$ or $\operatorname{AgC}(\mathrm{B}, \mathrm{D})$ at a concentration of $3 \mu \mathrm{g} / \mathrm{mL}$ for 18 days. The Caco-2 monolayer and the Caco-2/HT29-MTX multilayer, as well as the Transwell membrane, are visible; silver spots are artificially labelled in red. Scale bar corresponds to $12 \mu \mathrm{m}$. 

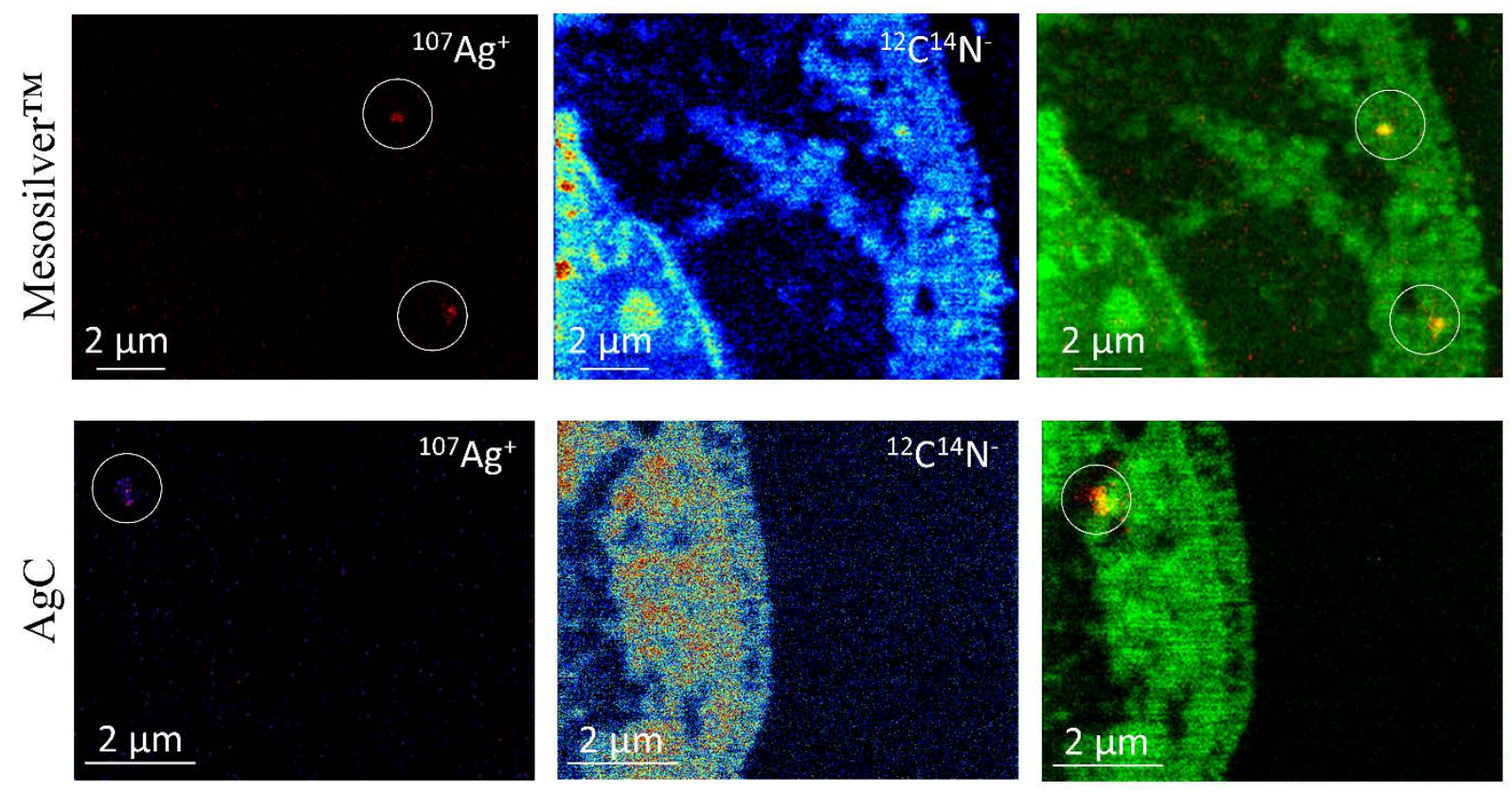

Figure 6. Distribution maps of Ag element (first column) and $\mathrm{CN}$ cluster (allowing visualization of the cell morphology, second column) detected by the Helium Ion Microscopy - Secondary Ion Mass Spectrometry (HIM-SIMS) instrument on Caco-2 cells cultured on Transwells and repeatedly exposed to Mesosilver ${ }^{\mathrm{TM}}$ or AgC at a concentration of $3 \mu \mathrm{g} / \mathrm{mL}$ for 18 days. The third column corresponds to image overlapping (silver in red, CN in green, overlapping of both in yellow). Silver spots are highlighted by white circles. Scale bar corresponds to $2 \mu \mathrm{m}$. 


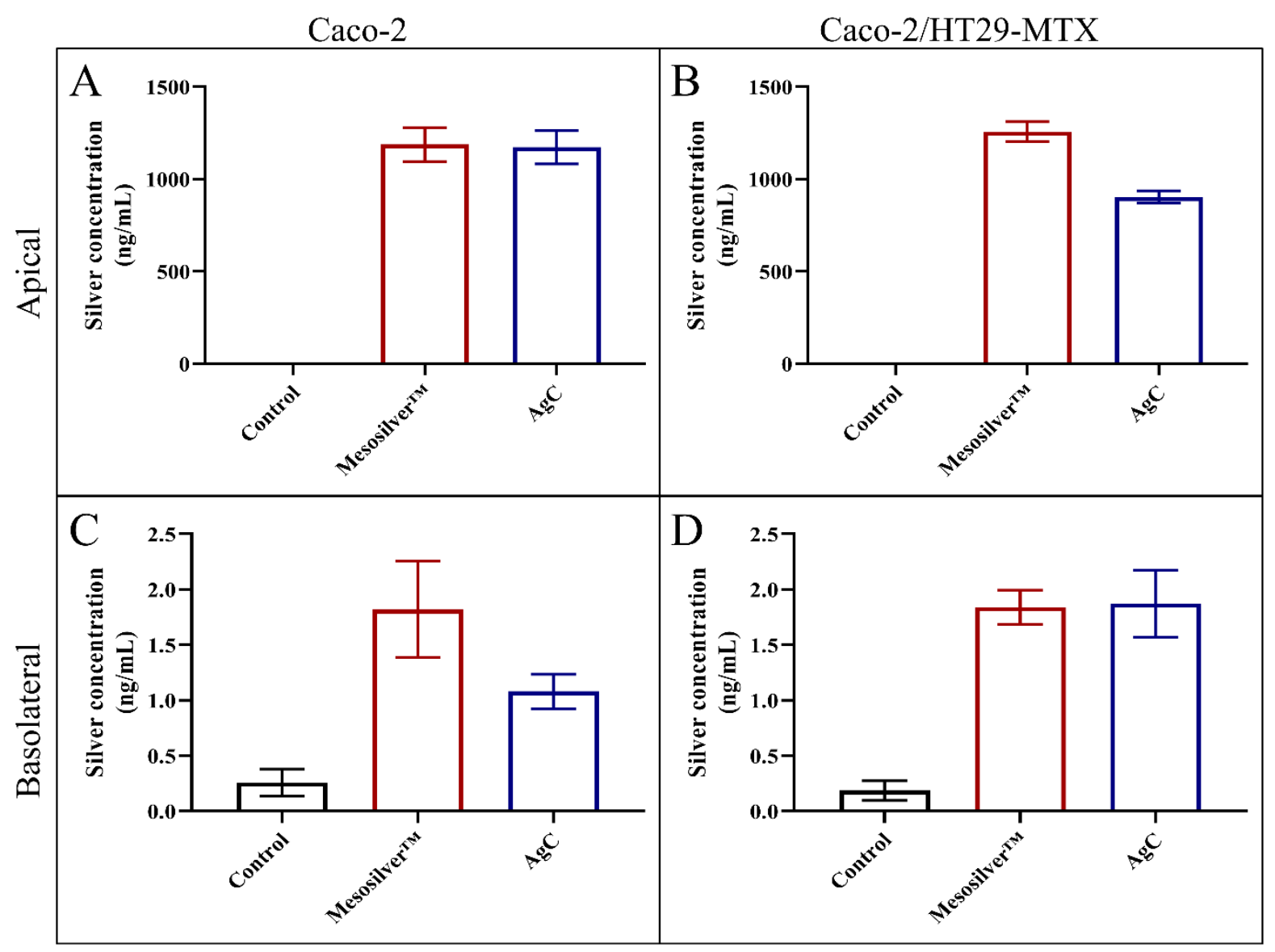

Figure 7. Total silver concentration measured by ICP-MS in apical (A,B) and basolateral (C,D) media after 18-day repeated exposure of Caco-2 cells (A,C) and Caco-2/HT29-MTX cells (B,D), cultured in Transwells, to Mesosilver ${ }^{\mathrm{TM}}$ or AgC at a concentration of $3 \mu \mathrm{g} / \mathrm{mL}$. LOD and LOQ are $0.241 \mathrm{ng} / \mathrm{mL}$ and $0.536 \mathrm{ng} / \mathrm{mL}$, respectively. 


\section{Supplementary Information}

\section{Material and Methods}

\section{Histology of Caco-2 and Caco-2/HT29-MTX cells}

Caco-2 and Caco-2/HT29-MTX (90/10) cells were cultured in Transwells for 28 days. Transwells were washed with PBS and fixed in Carnoy's fixative (60\% (v/v) ethanol, 30\% (v/v) chloroform, 10\% (v/v) glacial acetic acid) for $20 \mathrm{~min}$. Thereafter, polycarbonate membranes were cut and processed by a Shandon ${ }^{\mathrm{TM}}$ Excelsior $^{\mathrm{TM}}$ ES Tissue Processor using the following program: $2 \times 60$ min anhydrous ethanol, $2 \times 60$ min butanol, $480 \mathrm{~min}$ butanol, $3 \times 80 \mathrm{~min}$ paraffin at $60{ }^{\circ} \mathrm{C}$. Samples were included in paraffin blocks using a HistoStar ${ }^{\mathrm{TM}}$ Embedding Workstation (Thermo Fisher Scientific). 5- $\mu \mathrm{m}$ transversal sections were made using a Microm $^{\text {TM }}$ HM 340 E microtome (Thermo Fisher Scientific) and attached on slides. Samples were deparaffinised using Ottix Plus ${ }^{\mathrm{TM}}$ (Microm Microtech, Brignais, France) and subsequently dehydrated by increasingly diluted ethanol-water series. Staining was performed by 2 min in Hematoxylin, 10 min in running water, 15 min in Alcian Blue solution (pH 3.0) followed by 5 min in running water, 2 min in Eosin, 2 min in 95\% (v/v) ethanol, 2 min in dry ethanol and ending with 3 baths of American Ottix Plus ${ }^{\mathrm{TM}}$, followed by mounting with Diamount mountant (DiaPath, Martinengo, Italy). Samples were imaged using a Nikon Eclipse 90i microscope fitted with a DXM 1200 F Digital Camera. Image sets were taken with 200x magnification.

\section{Immunostaining of Caco-2/HT29-MTX cells for mucus detection}

At the end of the 18-day exposure period to the Mesosilver ${ }^{\mathrm{TM}}$ or AgC suspension (concentration of $3 \mu \mathrm{g} / \mathrm{mL}$ ), Caco-2/HT29-MTX cells were fixed with 4\% (w/v) paraformaldehyde in PBS and 
permeabilized with $0.5 \%(\mathrm{v} / \mathrm{v})$ Triton X-100. Untreated cells were also considered as control. After PBS washing, cells were blocked in PBS with 3\% (w/v) BSA and 0.1\% (v/v) Igepal (Sigma) overnight. After blocking, cells were incubated with a rabbit anti Muc5AC (Abcam, Paris, France) at a 1:250 dilution, followed by incubation with Alexa Fluor 594 goat anti-rabbit IgG antibody (Invitrogen) at a 1:100 dilution. Transwell membranes were cut with a scalpel and mounted using ProLong Gold antifade reagent with DAPI (4',6-diamidino-2-phenylindole, Invitrogen). Slides were visualized under a $20 \times$ objective on a TCS SP8 AOBS inverted confocal microscope (Leica Microsystems, Mannheim, Germany).

\section{Table and figures}

Table S1. Main characteristics of Mesosilver ${ }^{\mathrm{TM}}$ in pure or diluted form (at a concentration of 3 $\mu \mathrm{g} / \mathrm{mL})$ in cell culture medium containing or not $2 \%(\mathrm{v} / \mathrm{v})$ FBS after $48 \mathrm{~h}$ of exposure.

\begin{tabular}{|c|c|c|c|c|c|c|c|}
\hline Mesosilver ${ }^{\mathrm{TM}}$ & $\frac{[\mathrm{FBS}]}{\%(\mathrm{v} / \mathrm{v})}$ & $\begin{array}{c}\text { Time } \\
(\mathrm{h}) \\
\end{array}$ & $\frac{\text { TEM_Diameter }}{}$ & $\begin{array}{c}\text { DLS_Diameter } \\
\text { (Maximum Peak - nm) }\end{array}$ & PDI & $\frac{\text { Zeta potential }}{(\mathrm{mV})}$ & $\mathrm{pH}$ \\
\hline In pure form & - & - & $12.0 \pm 4.1$ & 79 & 0.60 & $-30.1 \pm 4.8$ & 7.3 \\
\hline \multirow{4}{*}{$\begin{array}{l}\text { In culture medium } \\
\text { at } 3 \mu \mathrm{g} / \mathrm{mL}\end{array}$} & 0 & 0 & - & 164 & 0.27 & $-9.2 \pm 0.2$ & 7.2 \\
\hline & 0 & 48 & - & 1281 & 0.45 & $-13.5 \pm 0.3$ & 7.7 \\
\hline & 2 & 0 & - & 79 & 0.22 & $-9.0 \pm 1.0$ & 7.2 \\
\hline & 2 & 48 & - & 91 & 0.47 & $-9.7 \pm 0.4$ & 7.7 \\
\hline
\end{tabular}


Caco-2 monoculture Caco-2/HT29-MTX co-culture

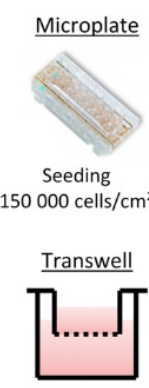

Treatment with Mesosilver ${ }^{\mathrm{TM}}$ or AgC over cell differentiation (repeated every $\mathbf{2}$ days)

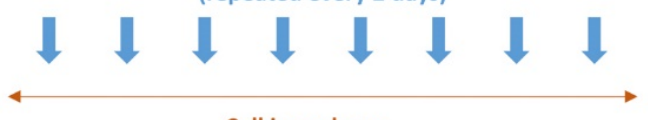

Cell impedance

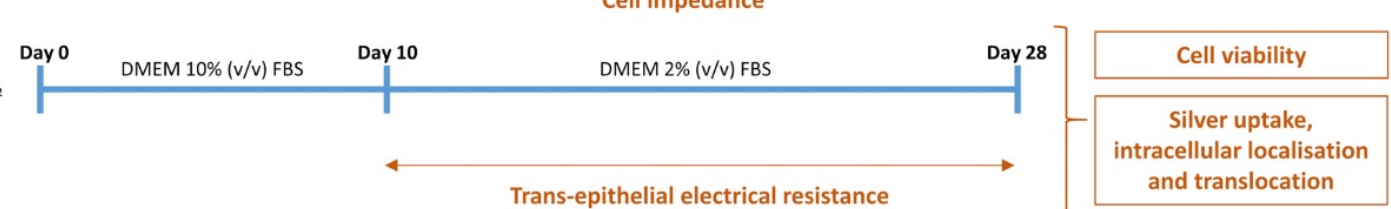

Figure S1. Schematic representation of repeated exposure of Caco-2 and Caco-2/HT29-MTX cells to Mesosilver ${ }^{\mathrm{TM}}$ and AgC. 


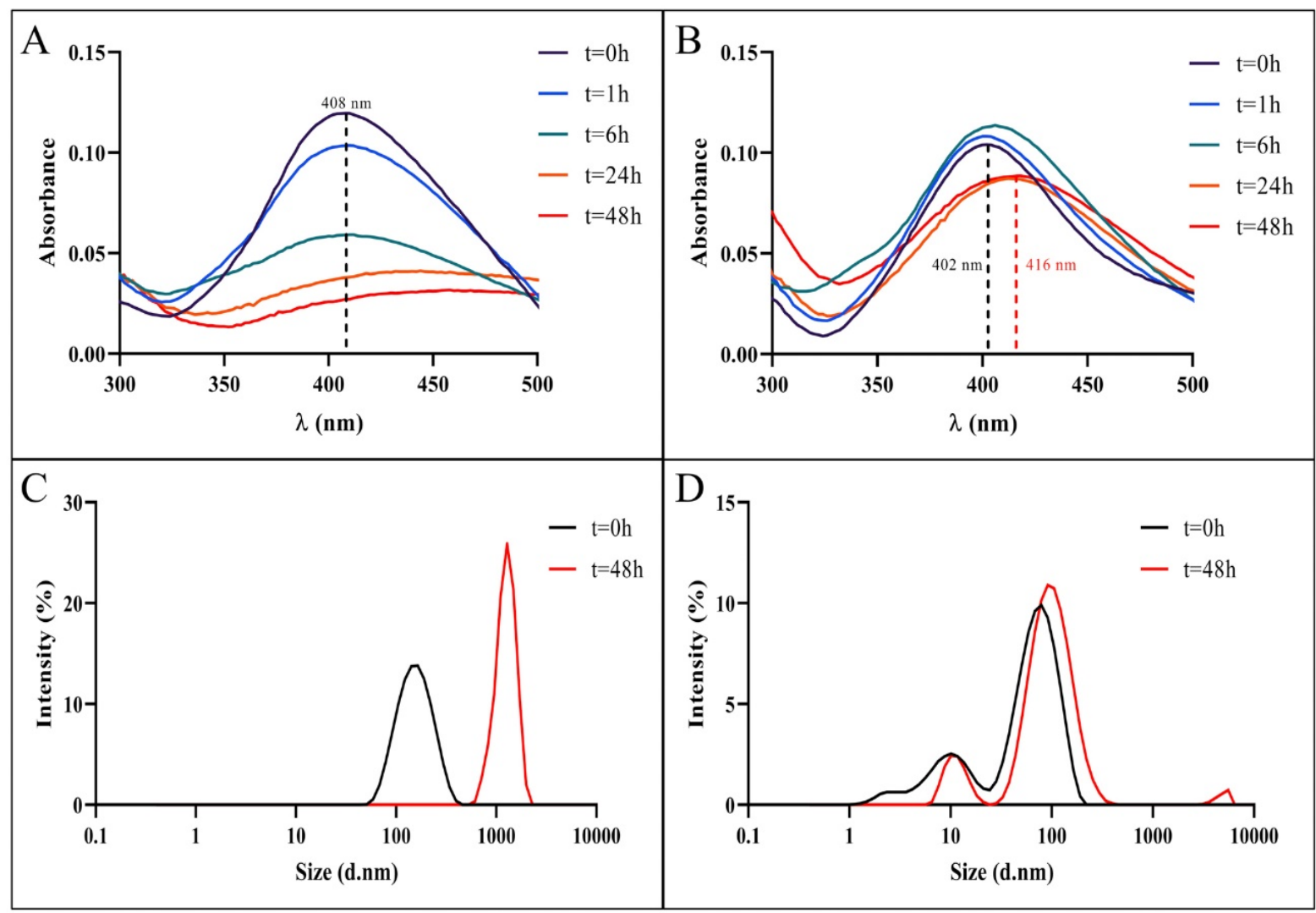

Figure S2. Physico-chemical characterization of Mesosilver ${ }^{\mathrm{TM}}$ at $3 \mu \mathrm{g} / \mathrm{mL}$ in cell culture medium without $(\mathrm{A}, \mathrm{C})$ or with $(\mathrm{B}, \mathrm{D}) 2 \%(\mathrm{v} / \mathrm{v})$ FBS. $(\mathrm{A}, \mathrm{B})$ Time variation of UV-vis absorbance during $48 \mathrm{~h}$ of exposure with the maximum absorption wavelength $\left(\lambda_{\max }\right)$ labelled; (C,D) hydrodynamic diameter distribution of AgNPs, initially and after $48 \mathrm{~h}$ of exposure, obtained from DLS measurements. 


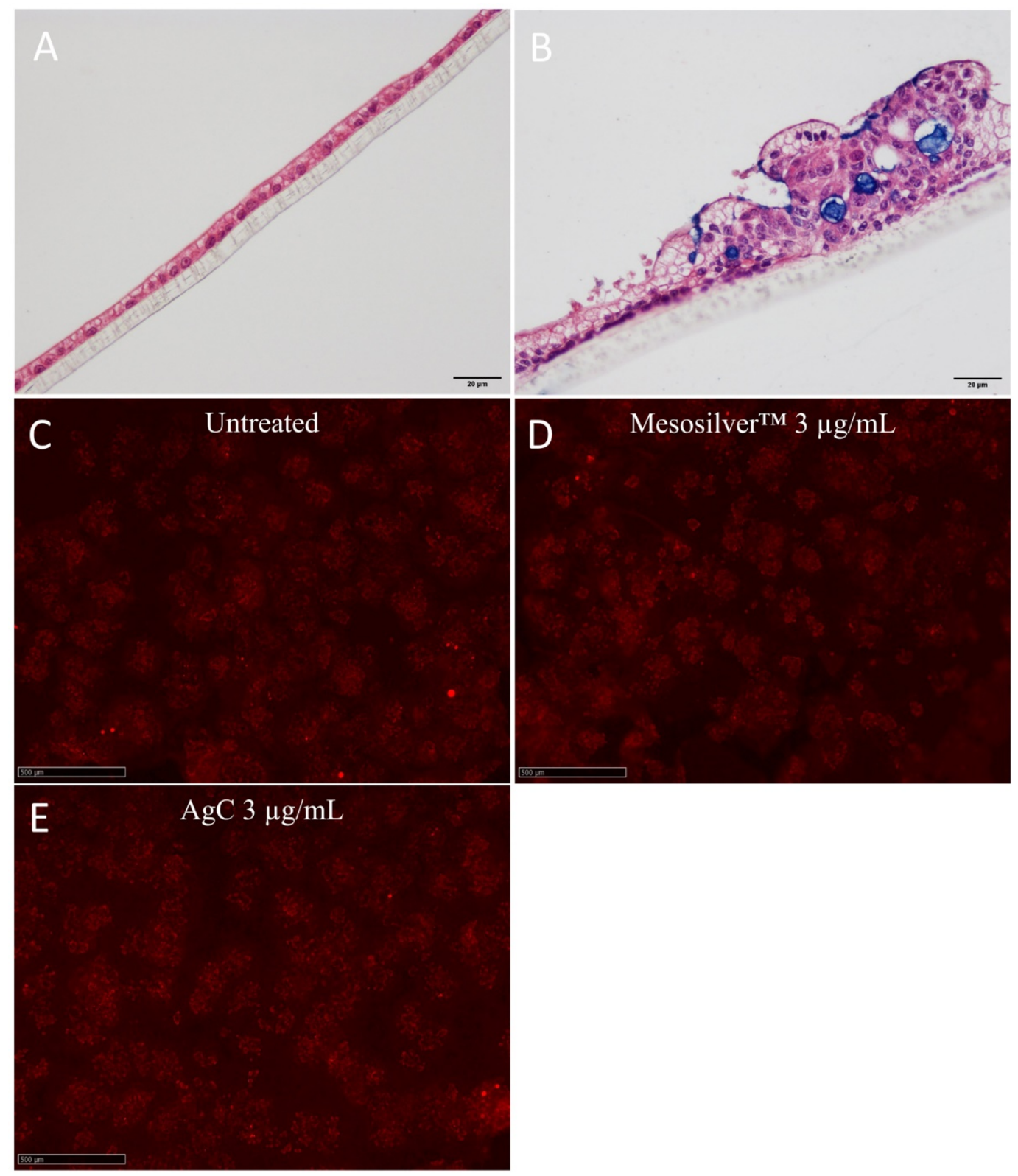

Figure S3. Characterization of in vitro cell models. (A,B) Representative images of Caco-2 monoculture (A) and Caco-2/HT29-MTX co-culture (B) after Hemalun \& Eosine staining with Alcian Blue; (C-E) MUC5AC immunofluorescence staining of Caco-2/HT29-MTX cells, untreated (C) or repeatedly exposed to Mesosilver ${ }^{\mathrm{TM}}$ (D) and AgC (E) at a concentration of 3 $\mu \mathrm{g} / \mathrm{mL}$ for 18 days. 
Calicheamicin $500 \mathrm{fM}-1 \mathrm{~h}$

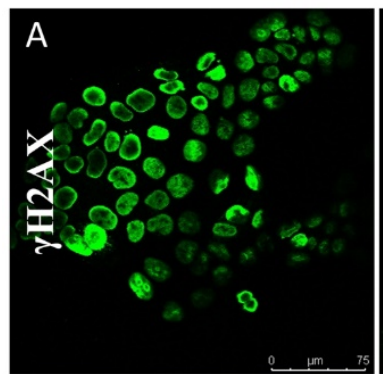

$\mathrm{E}$

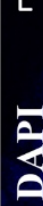

Untreated

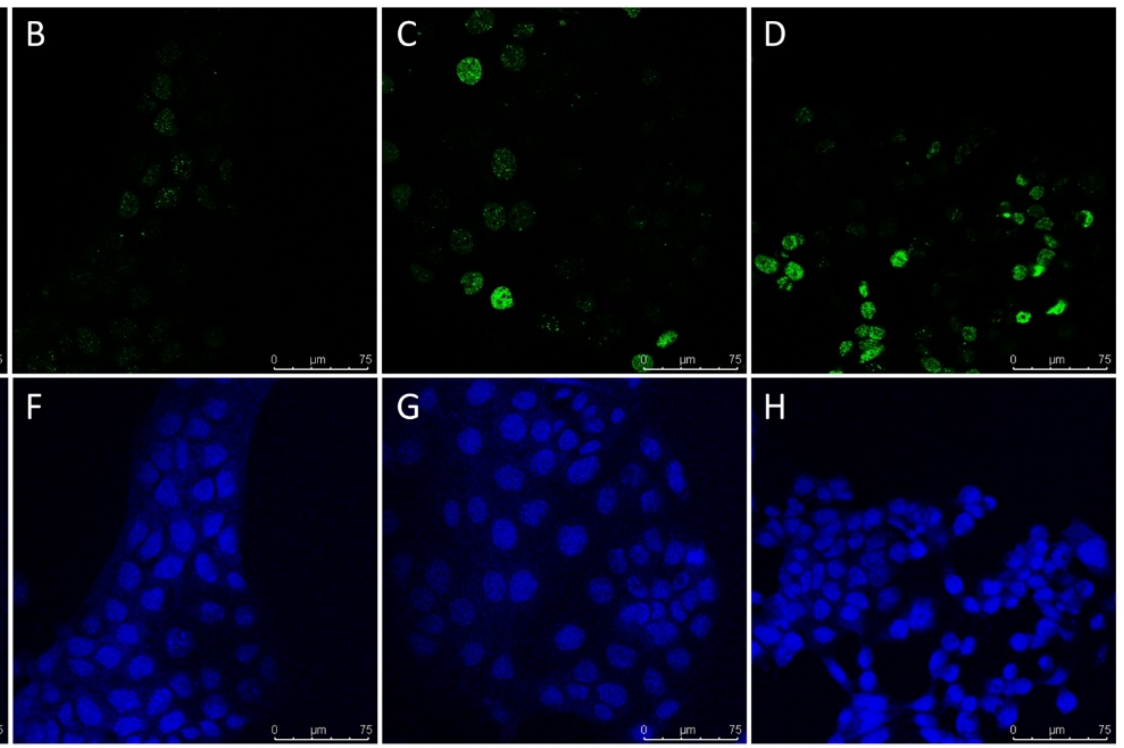

$\mathrm{AgC}$

$1 \mu \mathrm{g} / \mathrm{mL}-6 \mathrm{~h}$

Figure S4. Representative images of genotoxicity induction by Mesosilver ${ }^{\mathrm{TM}}$ or $\mathrm{AgC}$ (concentration of $1 \mu \mathrm{g} / \mathrm{mL}$ ) on Caco-2 proliferating cells after a $6 \mathrm{~h}$ acute exposure. Genotoxicity induction was measured by $\gamma \mathrm{H} 2 \mathrm{AX}$ immunofluorescence staining (A-D); DAPI was used to stain cell nucleus (E-H). Positive control with $500 \mathrm{fM}$ calicheamicin (A,E); untreated cells (B,F); cells exposed for $6 \mathrm{~h}$ to $1 \mu \mathrm{g} / \mathrm{mL} \operatorname{Mesosilver}^{\mathrm{TM}}(\mathrm{C}, \mathrm{G})$ or AgC (D,H). Scale bar corresponds to $75 \mu \mathrm{m}$. 